\title{
ОЦЕНКА НАЧАЛЬНЫХ И ПРОГНОЗНЫХ (ПЕРСПЕКТИВНЫХ И ПРОГНОЗИРУЕМЫХ) ГЕОЛОГИЧЕСКИХ И ИЗВЛЕКАЕМЫХ РЕСУРСОВ НЕФТИ ЗАПАДНО-СИБИРСКОЙ НЕФТЕГАЗОНОСНОЙ ПРОВИНЦИИ И ИХ СТРУКТУРЫ
}

Конторович А. Э., Лившиц В. Р., Бурштейн Л. М., Курчиков А. Р.

\begin{abstract}
Аннотация
Рассматривается количественная оценка структуры начальных и прогнозных ресурсов нефти Западно-Сибирской нефтегазоносной провинции. Метод основан на законе распределения скоплений углеводородов по массе - усеченном распределении Парето и имитационном моделировании генеральной совокупности залежей нефти. Такой подход позволяет оценить количество и суммарные ресурсы нефти, сосредоточенные в любых интервалах крупности, в частности, в интервалах мелких и мельчайших месторождений, с целью определения экономической эффективности их разработки. Рассмотренные оценки не относятся к нетрадиционным ресурсам, таким как сланцевая нефть баженовской свиты.
\end{abstract}

\section{Ключевые слова:}

нефтегазовые провинции, ресурсы и запасы нефти, усеченное распределение Парето, геологоразведочный фильтр, генеральная совокупность месторождений, выборка с пристрастием, прогноз структуры геологических и извлекаемых ресурсов. 


\title{
ОЦЕНКА НАЧАЛЬНЫХ И ПРОГНОЗНЫХ (ПЕРСПЕКТИВНЫХ И ПРОГНОЗИРУЕМЫХ) ГЕОЛОГИЧЕСКИХ И ИЗВЛЕКАЕМЫХ РЕСУРСОВ НЕФТИ ЗАПАДНО-СИБИРСКОЙ НЕФТЕГАЗОНОСНОЙ ПРОВИНЦИИ И ИХ СТРУКТУРЫ
}

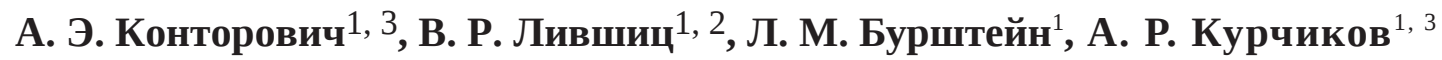 \\ 1 Институт нефтегазовой геологии и геофизики им. А.А. \\ Трофимука СО РАН, 630090, Новосибирск, просп. академика \\ Коптюга, 3, Россия \\ 2 Новосибирский государственный университет, 630090, \\ Новосибирск, ул. Пирогова, 2, Россия \\ ${ }^{3}$ Тюменский государственный нефтегазовый университет \\ 625000, Тюмень, ул. Володарского, 38, Россия
}

Рассматривается количественная оценка структуры начальных и прогнозных ресурсов нефти Западно-Сибирской нефтегазоносной провинции. Метод основан на законе распределения скоплений углеводородов по массе - усеченном распределении Парето и имитационном моделировании генеральной совокупности залежей нефти. Такой подход позволяет оценить количество и суммарные ресурсы нефти, сосредоточенные в любых интервалах крупности, в частности, в интервалах мелких и мельчайших месторождений, с целью определения экономической эффективности их разработки. Рассмотренные оценки не относятся к нетрадиционным ресурсам, таким как сланцевая нефть баженовской свиты.

нефтегазовые провинци, ресурсы и запасы нефти, усеченное распределение Парето, геологоразведочный фильтр, генеральная совокупность месторождений, выборка с пристрастием, прогноз структуры геологических и извлекаемых ресурсов.

Проблема оценки величины и структуры региональных и глобальных геологических и извлекаемых ресурсов, в начале нефти, а вскоре газа и конденсата возникла в 30-х годах XX века. И. М. Губкин был одним из инициаторов таких оценок [Губкин, 1950 а, б; Геологическое строение..., 1958; Гурари и др., 1963, Конторович, 2017].

Оценка массы (объема) и структуры ресурсов углеводородов (УВ) в каждом нефтегазоносном бассейне должна, как минимум, давать ответы на следующие вопросы. 
На начальных стадиях изучения бассейнов естественно возникает вопрос, есть ли в изучаемом бассейне месторождения уникальные по запасам, гигантские, крупные [Трофимук, 1959, 1991 а, б; Конторович, Демин, 1977] ? По мере исчерпания в бассейне крупных месторождений естественным образом возникает вопрос, остались ли в этих бассейнах месторождения мелкие, средние, мельчайшие, сколько их, какие ресурсы в них сосредоточены?

Ранее всего, в конце 60-х, начале 70-х годов XX века этот вопрос возник перед американскими геологами. Но лично авторы видели немного работ, в которых бы они были подняты на необходимую теоретическую высоту.

Кроме того, стало очевидно, что проблема количественной оценки перспектив нефтегазоносности распадается на широкий спектр самостоятельных и достаточно сложных задач в зависимости от фазового состояния углеводородов, типа коллектора и пр. Приведем только некоторые из них: классические (традиционные) залежи нефти и газа, классические (традиционные) газонефтяные и нефтегазовые залежи, залежи конденсатного газа, залежи гидратного газа, скопления водорастворенного метанового или преимущественно метанового газа и др. Очень скоро стало ясно, что в особые классы скоплений углеводородов должны быть выделены залежи в низко пористых и низко проницаемых породах-коллекторах, залежи тяжелой, смолистой, сернистой, нафтеновой нефти и т. п. По существу, каждый такой объект поисков и разведки порождает самостоятельную задачу и для каждой из них должен был быть найден свой набор в значительной мере специфических методов оценки ресурсов, поисков, разведки, разработки и переработки.

В последнее десятилетие набор таких сырьевых углеводородных объектов дополнился так называемой «сланцевой нефтью». Как нередко бывает в науке, это открытие, обычно приписываемое американским геологам, принадлежит собственно не только им. Еще в 1961 г. геолог редкого таланта Ф.Г. Гурари теоретически предсказал возможность получения нефти из баженовской свиты в Западной Сибири [Гурари, 1961]. Восемь лет спустя выдающиеся Западно-Сибирские геологи следующего поколения Ф. К. Салманов, И.И. Нестеров, Г. Р. Новиков и А. В. Тян получили фонтан такой нефти из баженовской свиты на Салымском месторождении. Теоретический анализ и геологоразведочная практика очень быстро показали, что в России и других странах Евразии есть множество таких бассейнов «сланцевой нефти». Перечислим наиболее известные из них. Помимо баженовской свиты источником такой нефти могут быть доманиковая свита востока Восточно-Европейской платформы, кумская свита КавказскоКрымского региона, куонамская свита Сибирской платформы и др., озерные сланцы 
Северо-Восточного Китая. Американские специалисты выделили десятки подобных бассейнов сланцевой нефти во многих регионах мира [Нефть и газ ..., 2014].

Великолепный обзор регионов сланцевой нефтеносности опубликовал О. М. Прищепа [Прищепа, 2019].

Естественно, что постановка проблемы стимулировала поиск методов ее решения. Методологически сразу наметилось два подхода - подход по аналогии и генетический. В советской, российской и мировой литературе опубликовано большое количество работ, поразному описывающих эти подходы [Количественная оценка..., 1988].

Кроме того, поскольку речь шла о количественной оценке, то сразу необходимо было определить и соответствующий математический аппарат. Было установлено [Прогноз месторождений..., 1981], что процессы генерации, миграции, аккумуляции и рассеяния УВ носят стохастический характер и, следовательно, требуют для своего описания использования аппарата теории вероятностей и математической статистики.

Как следствие, сразу возник вопрос о распределении месторождений УВ по величине запасов. Знание этого закона, оказалось чрезвычайно важно, как для теории нафтидогенеза, так и для практики количественной оценки перспектив нефтегазоносности [Шпильман 1972, 1982; Конторович, Демин, 1977, 1979; Конторович, Лившиц, 1988; Прогноз месторождений..., 1981; Количественная оценка..., 1988; Kontorovich и др., 2001].

Очевидный подход к установлению закона распределения скоплений УВ по массе эмпирический, основанный на статистической обработке данных по величинам запасов открытых месторождений в хорошо изученных нефтегазоносных провинциях. Однако, такой подход привел ряд исследователей [Бакиров, 1972; Буялов и др., 1975; Кауфман и др., 1975], к ошибочному выводу о логарифмически нормальном законе распределения месторождений в нефтегазоносном бассейне (НГБ), по запасам. Их ошибка состояла в том, что они отождествляли совокупность открытых месторождений, с представительной выборкой из всех месторождений НГБ, не учитывая того факта, что вероятность открытия месторождения тем больше, чем больше величина его запасов и множество открытых месторождений представляет собой «выборку с пристрастием» [Конторович и др., 1976].

Вероятно, первым, кто обратил внимание на ошибочность подобного подхода, был В. И. Шпильман [Шпильман, 1972]. Им же было введено понятие геологоразведочного фильтра и определен степенной характер распределения месторождений по запасам в НГБ, как «закон обратных квадратов» [Шпильман, 1972, 1982].

В результате многолетних исследований А. Э. Конторовича и В. И. Демина, направленных на решение общей задачи поиска закона распределения месторождений 
углеводородов в нефтегазоносных бассейнах по запасам, ими была выполнена статистическая обработка данных о величинах запасов открытых месторождений по большому числу хорошо изученных НГБ мира и получено более общее выражение для распределения месторождений нефти и газа по величине запасов - усеченное распределение Парето [Конторович, Демин, 1977, 1979; Прогноз месторождений..., 1981; Количественная оценка..., 1988]. Распределение, полученное этими авторами, имеет вид $\left[x_{0}, x_{m}\right]$,

$$
\varphi(x)=C\left(\frac{1}{x^{\lambda}}-\frac{1}{x_{m}^{\lambda}}\right),
$$

где $x-$ масса УВ в скоплении, $x_{0} \leq x \leq x_{m}$

$x_{0}$ и $x_{m}-$ минимальное и максимальное значения массы скопления,

$1<\lambda<3$ - параметр распределения,

$$
C=\frac{(\lambda-1) x_{m}^{\lambda}}{x_{0}\left[\lambda-1+\left(\frac{x_{m}}{x_{0}}\right)^{\lambda}\right]-\lambda x_{m}} \text {, нормирующий множитель. }
$$

Как было показано А.Э. Конторовичем и В.Р. Лившицем совокупность открытых месторождений не противоречит гипотезе о логарифмически нормальном законе распределения лишь на определенных этапах изучения НГБ [Конторович, Лившиц, 1988; Количественная оценка..., 1988].

Дальнейшие исследования Н.А. Крылова, А.Г. Алексина, Ю.Н. Батурина, [Крылов и др., 1986], а также Ю.А. Арсирия, Б.П. Кобышева, Д.И. Чупрынина [Арсирий и др., 1986] и В. И. Шпильмана и Ч. Ц. Цзиня [Шпильман, Цзин, 1993], подтвердили справедливость результатов В. И. Шпильмана, А. Э. Конторовича, В. И. Демина.

Важно, что, независимо от геологического строения и истории развития НГБ, его индивидуальные особенностей, функциональный вид закона распределения скоплений УВ по величине запасов сохраняется одним и тем же, отличаясь лишь значениями своих параметров. Это обстоятельство позволяет утверждать, что такой характер распределения скоплений УВ по массе является не частной аппроксимацией для конкретного НГБ, а носит универсальный, фундаментальный характер [Нестеров, Шпильман, 1985, 1987; Конторович, 1991].

Здесь также следует отметить работы Л. М. Бурштейна [Бурштейн, 2004, 2006], построившего математическую модель формирования распределения скоплений УВ по крупности, основанную на скоростях аккумуляции и диссипации нефти при 
формировании и разрушении залежи и предложившего методику оценки параметров распределения для слабоизученных бассейнов.

Кроме того, в [Лившиц, 2020] показано, что при степенном характере распределения по массе залежей УВ, распределение их месторождений также будет иметь аналогичный вид.

В настоящее время, степенной характер распределения месторождений УВ по величине запасов, не вызывает возражений у подавляющего большинства исследователей.

\section{ЗАПАДНО-СИБИРСКАЯ НЕФТЕГАЗОНОСНАЯ ПРОВИНЦИЯ: ИСТОРИЯ ИЗУЧЕНИЯ И ВЫЯВЛЕНИЯ ЗАЛЕЖЕЙ НЕФТИ И ГАЗА}

Даже задача оценки начальных геологических и извлекаемых традицонных ресурсов нефти оказалась не такой простой, как это казалось ранее. Возьмем в качестве примера ставший эталоном для решения многих фундаментальных и прикладных задач геологии и разведки нефтяных и газовых месторождений Западно-Сибирский осадочный бассейн. Оценка его начальных ресурсов всегда выполнялась методами количественной или качественной внутренней аналогии. Наибольший вклад в количественную оценку перспектив нефтегазоносности Западно-Сибирского бассейна внесли Ф.Г. Гурари, А.Э. Конторович, В.Д. Наливкин, И.И. Нестеров, Н.Н. Ростовцев, Ф.К. Салманов, Г.П. Сверчков, А.А. Трофимук, В.И. Шпильман, Ю.Г. Эрвье, А.М. Брехунцов, Л.М. Бурштейн, Н.В. Судат, Л.О. Сулейманова и др.

В провинции нефтеносны отложения палеозоя, юры и мела, в их составе выделены следующие нефтегазоносные комплексы: палеозойский, зоны контакта палеозоя и мезозоя (НГГЗК), нижней-средней юры $\left(\mathrm{I}_{1}-\mathrm{I}_{2}\right)$, кимеридж-оксфордский, баженовский (волжско-раннебериасский), берриас - нижнеаптский, нижнего - верхнего мела - апт, альб, сеноманский.

По состоянию на 01.01. 2019 г. в Западно-Сибирской провинции было открыто 6594 залежи нефти с запасами более 30 тыс. т. (табл. 1), из них извлекаемые запасы более 300 млн т. имело 8 залежей, запасы от 100 до 300 млн т. - 39 залежей, запасы 30 до 100 млн т. 141 залежь, запасы от 10 до 30 млн т. - 328 залежи, запасы от 3 до 10 млн т. - 895 залежей. Преобладают залежи с запасами менее 3 млн т. (табл. 1). Самые большие суммарные извлекаемые запасы нефти (7230 млн т.) среди открытых залежей имеют залежи с извлекаемыми запасами от 30 до 100 млн т.

В таблицах 2 и 3 показано распределение начальных геологических и извлекаемых запасов нефти по месторождениям и залежам различной крупности.

Организация геологоразведочных работ в Западно-Сибирской провинции была 
такова, что с самого начала при выявлении месторождений действовал механизм геологоразведочного фильтра (табл. 4 и 5) [Конторович и др., 1985, 1987; Конторович и др., 1988б, 1988в]. В табл. 4 показано, что все месторождения с извлекаемыми запасами более 300 млн т. были выявлены до 2001 г. Пик их открытий имел место в 1960-1970 гг. Месторождения с извлекаемыми запасами от 100 до 300 млн т. были открыты к 2011 г., а максимальное их число было открыто в 1971-1980 гг. Из табл. 4 видно, что с уменьшением средних запасов месторождений пик их открытия приходится на все более поздний временной этап освоения Западно-Сибирской провинции.

В табл. 5 показана последовательность выявления запасов в месторождениях различной крупности. Нужно только иметь в виду, что запасы гигантских и крупных месторождений, разведка которых и соответственно прирост запасов длятся несколько лет (иногда до 7-10 лет), в принятой для табл. 5 форме свертывания информации привязаны к году открытия месторождения. Наиболее интенсивно запасы нефти в провинции выявлялись в 1960- 1970 гг. Из таблиц 4 и 5 также видно, что в ЗападноСибирской провинции все месторождения с запасами более 100 млн т были выявлены к 2011 г. Пики открытия месторождений с извлекаемыми запасами от 3 до 30 и от 0,3 до 10 млн т. имели место в 1981-1990 и 2001-2010 гг.

Описанное действие геологоразведочного фильтра иллюстрирует рисунок.

Естественно возникают новые вопросы и задачи, которые требуют решения. Сколько осталось в Западно-Сибирской провинции невыявленных месторождений нефти? Каковы ресурсы нефти в них? Как было отмечено в работе [Конторович, Лившиц, 2017] применявшиеся в течение всей второй половины XX в. методы количественной оценки перспектив нефтегазоносности не позволяют решить эти задачи. Их решение может быть получено в рамках теоретического подхода, разработанного А.Э. Конторовичем, В.И. Шпильманом, В.И. Деминым, В.Р. Лившицем и др. (см. выше).

\section{ОЦЕНКА НАЧАЛЬНЫХ И ПРОГНОЗНЫХ РЕСУРСОВ НЕФТИ В ЗАПАДНО- СИБИРСКОЙ НЕФТЕГАЗОНОСНОЙ ПРОВИНЦИИ}

Располагая информацией о всех выявленных в Западно-Сибирской провинции залежах нефти и газа, количестве и начальных геологических запасах залежей с извлекаемыми запасами более 3 млн т. и их дифференциации по классам крупности, авторы по методике А.Э. Конторовича и В.И. Демина [Конторович, Демин, 1977, 1979] нашли параметры усеченного распределения Парето, описывающего эту выборку и экстраполировали его в область залежей с мельчайшими запасами вплоть до извлекаемых запасов 30 тыс. т. Граница минимальных залежей была выбрана с учетом 
запасов залежей нефти, которые реально ставит в настоящее время на баланс Государственная комиссия по запасам Российской Федерации (ГКЗ России).

Если ограничить усеченное распределение Парето слева (минимальное значение массы учитываемых скоплений) величиной $\theta_{0}=0.03$ млн т., то при этом величина начальных геологических и извлекаемых ресурсов нефти составит 204112,4 и 56664,7 млн т., а значение параметра $\lambda$ усеченного распределения Парето -2.11 .

Затем при найденных параметрах усеченного распределения Парето было выполнено имитационное моделирование и получено более 100 выборок распределения залежей по запасам в Западно-Сибирской провинции. Из множества реализаций экспертно была выбрана одна из них, которая наиболее точно соответствовала полученной при геологоразведочном процессе выборке и распределению по запасам наиболее крупных месторождений [Конторович, Лившиц, 1988a; Kontorovich et al., 2001]. Для крупнейших месторождений была выбрана реализация близкая к ним индивидуально.

Полученная в результате оценка начальных геологических и извлекаемых ресурсов нефти в Западно-Сибирской провинции, количества залежей и их распределения по классам крупности приведена в табл. 6.

При этом нужно иметь ввиду, что полученная оценка справедлива только в рамках изученной выборки, которая является частью генеральной совокупности. В частности, для Западно-Сибирской провинции полученная оценка не распространяется на баженовскую свиту, которая представляет собой самостоятельный уникальный объект.

Коэффициент извлечения нефти в каждом классе крупности был принят средним по подсчетам ГКЗ России для каждого из классов (табл. 7).

В табл. 8 с учетом данных о начальных разведанных запасах (см. табл. 1) приведены данные о прогнозных (включая ресурсы категории $\mathrm{D}_{0}$ ) ресурсах нефти и их распределению по залежам разных размеров. Видно, что, если принять в качестве минимальных извлекаемых запасов рентабельных для разработки залежей в ЗападноСибирской НГП 30 тыс. т., то в провинции не выявлено еще 186478 залежей нефти, в том числе с запасами 3-10 млн т. - 414, 1-3 млн т. - 2610, с запасами 0.3-1.0 млн т. 11930, 0.1-0.3 млн т. - 37430 и с запасами 0.03-0.10 млн т. - 134094 залежей. При такой оценке извлекаемые прогнозные ресурсы нефти в провинции составляют 25 млрд 275,9 млн т.

В зависимости от цен на нефть на мировых и внутреннем российском рынках минимальные размеры рентабельных для разработки залежей могут меняться. Соответственно, будут меняться и оценки начальных и прогнозных ресурсов нефти. В 
табл. 9 приведены оценки начальных геологических и извлекаемых ресурсов нефти в Западно-Сибирской провинции при разных минимальных запасах залежей, учитываемых при оценке.

В табл. 10 приведена структура начальных суммарных геологических и извлекаемых ресурсов нефти в Западно-Сибирской провинции с распределением на накопленную добычу, запасы категорий $\mathrm{A}+\mathrm{B}+\mathrm{C}_{1}, \mathrm{C}_{2}$ и прогнозные ресурсы категории $\mathrm{D}_{1}$ при минимальных запасах залежей, учитываемых при оценке 0.03 млн т., 0.1 млн т. и 0.3 млн т.

Минимальными объектами оценки были залежи нефти (см. табл. 10). Между тем в Западно-Сибирской провинции преобладают многопластовые месторождения нефти. Статистические данные о количестве залежей в месторождениях провинции приведены в табл. 11.

Видно, что статистически больше всего залежей в крупных месторождениях. Больше всего залежей (215) в Вынгапуровском месторождении, в Красноленинском - 163. В Тайлаковском месторождении выявлено 159 залежей, в Еты-Пуровском и Самотлорском месторождениях по — 99, в Приобском — 96 и т.д.

Для составления программ лицензирования недр, проектирования геологоразведочных работ и экономической оценки рентабельности освоения лицензионных участков важно также располагать информацией о распределении по запасам неоткрытых месторождений нефти (прогнозные ресурсы) и вероятном количестве залежей в них.

В связи с этим в настоящей работе метод имитационного моделирования был использован также для прогноза распределения количества месторождений и их суммарных ресурсов по классам крупности. Для первых трех, самых крупных по запасам классов (с запасами месторождений более 30 млн т.) в соответствии с результатами, изложенными выше, количество месторождений, их запасы, количество и запасы залежей в этом классе принималось в соответствии с результатами геологоразведочных работ (см. табл. 11). Совокупность месторождений моделировалась из полученного ранее множества залежей. Алгоритм формирования прогнозной совокупности месторождений описан в [Конторович, Лившиц, 2017], а соответствующие результаты приведены в таблицах 12 и 13.

В табл. 14 приведено с дифференциацией по классам залежей распределение начальных извлекаемых ресурсов нефти (в млн т.): в генеральной совокупности залежей (ГС), накопленной добыче и разведанных запасах; в открытых залежах (ОЗ - выборке) и в прогнозных ресурсах, т. е. в невыявленных залежах (Н3). В табл. 15 те же данные 
приведены в \% от начальных ресурсов в каждом классе. Видно, что все ресурсы, которые были аккумулированы в залежах с извлекаемыми запасами более 10 млн т. уже выявлены, в залежах с извлекаемыми запасами 3,0-10.0 млн т. выявлено 71,2\% ресурсов, в залежах с извлекаемыми запасами 1,0-3.0 млн т. выявлено 34,5\% ресурсов. Процесс выявления залежей с запасами менее 1,0 млн т только начинается: в классе залежей с запасами 0,3-1,0 млн т. выявлено 13 \% ресурсов, в классе залежей с запасами $0.1-0.3$ млн т выявлено 3,9 ресурсов, с запасами $0.1-0.03$ млн т - всего 0,9 \%.

В таблицах 16 и 17 те же данные приведены для количества залежей разных классов.

Наконец, в таблицах 18 и 19 приведена информация о прогнозных ресурсах нефти в Западно-Сибирской нефтегазоносной провинции с дифференциацией по залежам и месторождениям различной крупности.

Благодарности. Авторы благодарны безвременно ушедшей Светлане Михайловне Каменецкой, которая много лет готовила фактический материал для работ этого цикла и без чего написание данной статьи было бы невозможным.

Источники финансирования. Работа выполнена в рамках базового проекта Минобрнауки № 0331-2019-0027, «Разработка методов количественной оценки нетрадиционных ресурсов нефти и газа (баженовская свита, мелкие и мельчайшие месторождения и пр.) и имитационной модели долгосрочного функционирования нефтегазового комплекса Российской Федерации. Оценка традиционных и нетрадиционных ресурсов осадочных бассейнов Сибири».

\section{ЛИТЕРАТУРА}

Арсирий Ю. А., Кабышев Б. П., Чупрынин Д. И., Шевченко А. Ф., Шевякова З. П. Прогноз размеров и числа неоткрытых залежей УВ и методика их поисков в ДДВ // Геология нефти и газа, 1986, № 10, с. 42-46.

Бакиров В.А. Статистическая модель распределения месторождений нефти и газа по величине запасов. Геология нефти и газа, 1972, №2, с. 63-68.

Буялов И.И., Вагеров В.С., Шунгутова С.А. Опыт применения логарифмически нормального закона распределения для оценки прогнозных запасов углеводородов. Реф. Науч.-техн. сб. ВНИИОЭНГ, сер. нефтегазов. геол. и геофииз., 1975, №6, с. 13-18.

Бурштейн Л. М. Возможный механизм формирования распределения скоплений углеводородов по крупности // Геология и геофизика, 2004, т. 45 (7), с. 815—825. 
Бурштейн Л. М. Статистические оценки параметров распределения скоплений нефти по величине в слабоизученных седиментационных бассейнах // Геология и геофизика, 2006, т. 47 (9), с. 1013-1023.

Геологическое строение и перспективы нефтегазоносности Западно-Сибирской низменности / Ред. Н.Н. Ростовцев. М., Госгеолтехиздат, 1958, 391 с.

Губкин И. М. Второе Баку // Избранные сочинения. В 2 т. М., Л., Изд-во АН СССР, 1950a, т. 1, с. $602-611$.

Губкин И. М. Урало-Волжская, или Восточная, нефтеносная область // Избранные сочинения. В 2 т. М., Л., Изд-во АН СССР, 1950б, т. 1, с. 527-601.

Гурари Ф.Г. О поисках нефти и газа в мезозое Западно-Сибирской низменности //Тр. СНИИГГИМС, вып.17. 1961. Л., Гостоптехиздат, с.15-31.

Гурари Ф. Г., Казаринов В. П., Миронов Ю. К. Наливкин В. Д., Нестеров И. И., Осыко Т. И., Ровнин Л. И., Ростовцев Н. Н., Рудкевич М. Я., Симоненко Т. Н., Соколов В. Н., Трофимук А. А., Чочиа Н. Г., Эрвье Ю. Г. Геология и нефтегазоносность Западно-Сибирской низменности - новой нефтяной базы СССР / Под ред. Н.Н. Ростовцева, А.А. Трофимука. Новосибирск, Наука, 1963, 201 с.

Количественная оценка перспектив нефтегазоносности слабоизученных регионов / А. Э. Конторович, Л. М. Бурштейн, Г. С. Гуревич и др. Под ред. А. Э. Конторовича. М.: Недра, 1988, 223 с.

Конторович А. Э. Общая теория нафтидогенеза. Базовые концепции, пути построения // Теоретические и региональные проблемы геологии нефти и газа. Новосибирск: Наука, Сибирское отделение, 1991. - с. 29-44.

Конторович А. Э. Разработка И. М. Губкиным парадигмы развития нефтяной промышленности СССР в XX веке // Геология и геофизика, 2017, т. (3-4), с. 351-365.

Конторович А. Э., Демин В. И. Метод оценки количества и распределения по запасам месторождений нефти и газа в крупных нефтегазоносных бассейнах // Геология нефти и газа, 1977, № 12, с. 18-26.

Конторович А. Э., Демин В. И. Прогноз количества и распределения по запасам месторождений нефти и газа // Геология и геофизика, 1979 (3), с. 26-46.

Конторович А. Э., Демин В. И., Краснов О. С. Прогноз подготовки ресурсов газа с применением математических методов//Повышением эффективности разработки и ускорение ввода в промышленное освоение месторождений газа в УССР.- Харьков, 1976. c. 69-70. 
Конторович А. Э., Демин В. И., Страхов И. А. Закономерности выявления различных по запасам месторождении нефти и газа в нефтегазоносных бассейнах // Геология и геофизика, 1985 (11), с. 3-16.

Конторович А. Э., Демин В. И., Страхов И. А. Закон геологоразведочного фильтра при поисках месторождений углеводородов // Советская геология, 1987, № 6, с. 7-13.

Конторович А. Э., Лившиц В. Р. Имитационная стохастическая модель распределения месторождений нефти и газа по запасам // Сов. геология, 1988а, № 9, с. 99-107.

Конторович А. Э., Лившиц В. Р. Математическая модель процесса поисков месторождений нефти и газа // Геология и геофизика, $1988 б$ (3). с. 3-8.

Конторович А.Э., Лившиц В.Р. Имитационное моделирование процесса поисков месторождений нефти и газа // Геология и геофизика, 1988в (5). с. 3-17.

Конторович А. Э., Лившиц В. Р. Новые методы оценки, особенности структуры и пути освоения прогнозных ресурсов нефти зрелых нефтегазоносных провинций (на примере Волго-Уральской провинции) // Геология и геофизика, 2017, т. 58, № 12, с. 18351852.

Крылов Н. А., Алексин А. Г., Батурин Ю. Н. Задачи и пути ускорения научнотехнического прогресса при поисках нефти в районах с высокой разведанностью недр // Геология нефти и газа, 1986, № 7, с. 1-7.

Лившиц В. Р. О законе распределения месторождений углеводородов по массе. Известия Томского политехнического университета. Инжиниринг георесурсов. 2020. Т. 331. № 6, c. 41-47.

Нестеров И. И., Шпильман В. И. Основы теории нефтегазонакопления // Основные проблемы геологии Западной Сибири. Труды ЗапСибНИГНИ. Вып. 200. - 1985. - с. 48-62.

Нестеров И. И., Шпильман В. И. Теория нефтегазонакопления // Недра - М. - 1987. 232 с.

Нефть и газ низкопроницаемых соанцевых толщ - резерв сырьевой базы углеводородов России / О. М. Прищепа, О. Ю. Аверьянова, А. А. Ильинский, Д. Морариу; под ред. О. М. Прищепы. - СПб.: ФГУП "ВНИГРИ", 2014. - 323 с.: ил. - (Труды ВНИГРИ).

Прищепа О. М. Состояние сырьевой базы и добычи трудноизвлекаемых запасов нефти в России // Минеральные ресурсы России. Экономика и управление. 2019, № 5, c. $14-20$.

Прогноз месторождений нефти и газа / А. Э. Конторович, Э. Э. Фотиади, В. И. Демин, В. Б. Леонтович, А. А. Растегин. М.: Недра, 1981. - 350 с.

Трофимук А. А. Открытие Урало-Волжской нефтеносной области - научный подвиг И.М. Губкина // Геология нефти и газа, 1959, № 4, с. 7-15. 
Трофимук А. А. О стратегии поисков нефти и газа в СССР. Новосибирск, 1991а, 64 с. (Препр./ ОИГГМ СО РАН; № 9).

Трофимук А. А. Поблемы развития газонефтедобывающей промышленности СССР // Теоретические и региональные проблемы геологии нефти и газа: Сб. науч. трудов. 1991б. - с. 6-14.

Шпильман В. И. Методика прогнозирования размеров месторождений // Труды Института Зап-СибНИГНИ., 1972, вып. 53, с. 118-126.

Шпильман В. И. Количественный прогноз нефтегазоносности. М., Недра, 1982, 215 c.

Шпильман В. И., Цзин Чжи Цзюнь. Закон распределения выявленных и невыявленных залежей нефти и газа по величине запасов // Геология нефти и газа, 1993, № 11 , с. 5-10.

Kaufman G.M., Balcer Y., Kruit D.A. Probabilistic model of oil and gas discovery // American Association of Petroleum Geologists. - 1975. - № 1. - P. 113-142.

Kontorovich A., Domain V., Livshitc V. Size distribution and dynamics of oil and gas field discoveries in petroleum basins //AAPG Bulletin, 2001, v. 85, № 9, p. 1609-1622. 
Рис. Последовательность выявления различных групп месторождений по запасам в ЗападноСибирской НГП с 1960 по 2018 гг. Классы месторождений: а). более 300 млн. т, б). 100-300 млн. т, в). 30 - 100 млн. т, г). 10 - 30 млн. т, д). 3 - 10 млн. т, е). 1 - 3 млн. т, ж). 0.3 - 1 млн. т, з). 0.1 - 0.3 млн. т, и). 0.03 - 0.1 млн. т 
Табл. 1. Начальные геологические и извлекаемые запасы нефти Западно-Сибирской НГП по состоянию на 01.01.2019 г., млн. т

\begin{tabular}{|c|c|c|c|c|c|c|c|c|c|c|}
\hline \multirow[b]{2}{*}{ Параметр } & \multicolumn{9}{|c|}{ Класс залежей по извлекаемым запасам } & \multirow[b]{2}{*}{ Всего } \\
\hline & более 300 & $100-300$ & $30-100$ & $10-30$ & $3-10$ & $1-3$ & $0.3-1$ & $\begin{array}{c}0.1- \\
0.3\end{array}$ & $0.03-0.1$ & \\
\hline Геологические & 8679.2 & 19136.9 & 22506.9 & 18461.2 & 17032.3 & 8111.8 & $\begin{array}{c}3567 . \\
2\end{array}$ & 1024.9 & 300.2 & 98820.7 \\
\hline Извлекаемые & 4042.0 & 6317.3 & 7230.1 & 5546.5 & 4840.8 & $\begin{array}{c}2192 . \\
6\end{array}$ & 911.3 & 246.4 & 61.7 & 31388.8 \\
\hline Количество залежей & 8 & 39 & 141 & 328 & 895 & 1229 & 1610 & 1327 & 1017 & 6594 \\
\hline
\end{tabular}



Табл. 2. Распределение начальных геологических запасов нефти на 01.01.2019 г. по месторождениям и залежам различной крупности в Западно-Сибирской НГП, млн. т

\begin{tabular}{|c|c|c|c|c|c|c|c|c|c|c|c|}
\hline \multirow{2}{*}{$\begin{array}{c}\text { Классы } \\
\text { залежей по } \\
\text { извлекаемым } \\
\text { запасам }\end{array}$} & \multirow[b]{2}{*}{ Параметры } & \multicolumn{9}{|c|}{ Классы месторождений по извлекаемым запасам } & \multirow[b]{2}{*}{ Всего } \\
\hline & & $\begin{array}{c}\text { более } \\
300\end{array}$ & $100-300$ & $30-100$ & $10-30$ & $3-10$ & $1-3$ & $0.3-1$ & $0.1-0.3$ & $0.03-0.1$ & \\
\hline \multicolumn{2}{|c|}{ Количество месторождений } & 15 & 50 & 109 & 137 & 179 & 156 & 118 & 32 & 10 & 806 \\
\hline \multicolumn{2}{|c|}{ Количество залежей } & 700 & 1551 & 1627 & 1192 & 795 & 409 & 233 & 63 & 24 & 6594 \\
\hline \multicolumn{2}{|c|}{ Суммарные запасы } & 37080.5 & 27070.7 & 19570.4 & 8992.8 & 4423.4 & 1271.2 & 364.3 & 40.7 & 6.7 & 98820.7 \\
\hline \multirow{2}{*}{ более 300} & Количество & 8 & 0 & 0 & 0 & 0 & 0 & 0 & 0 & 0 & 8 \\
\hline & Запасы & 8679.2 & 0.0 & 0.0 & 0.0 & 0.0 & 0.0 & 0.0 & 0.0 & 0.0 & 8679.2 \\
\hline \multirow{2}{*}{$100-300$} & Количество & 31 & 8 & 0 & 0 & 0 & 0 & 0 & 0 & 0 & 39 \\
\hline & Запасы & 15217.8 & 3919.1 & 0.0 & 0.0 & 0.0 & 0.0 & 0.0 & 0.0 & 0.0 & 19136.9 \\
\hline \multirow{2}{*}{$30-100$} & Количество & 31 & 73 & 37 & 0 & 0 & 0 & 0 & 0 & 0 & 141 \\
\hline & Запасы & 5694.4 & 11799.3 & 5013.2 & 0.0 & 0.0 & 0.0 & 0.0 & 0.0 & 0.0 & 22506.9 \\
\hline \multirow{2}{*}{$10-30$} & Количество & 62 & 87 & 126 & 53 & 0 & 0 & 0 & 0 & 0 & 328 \\
\hline & Запасы & 3779.2 & 4874.4 & 6956.1 & 2851.4 & 0.0 & 0.0 & 0.0 & 0.0 & 0.0 & 18461.2 \\
\hline \multirow{2}{*}{$3-10$} & Количество & 111 & 208 & 239 & 195 & 142 & 0 & 0 & 0 & 0 & 895 \\
\hline & Запасы & 2339.4 & 3784.8 & 4785.8 & 3603.3 & 2519.0 & 0.0 & 0.0 & 0.0 & 0.0 & 17032.3 \\
\hline \multirow{2}{*}{$1-3$} & Количество & 133 & 304 & 249 & 222 & 185 & 136 & 0 & 0 & 0 & 1229 \\
\hline & Запасы & 928.5 & 1737.5 & 1673.2 & 1633.8 & 1254.9 & 883.8 & 0.0 & 0.0 & 0.0 & 8111.8 \\
\hline \multirow{2}{*}{$0.3-1$} & Количество & 152 & 347 & 363 & 278 & 208 & 134 & 128 & 0 & 0 & 1610 \\
\hline & Запасы & 347.9 & 693.2 & 813.5 & 619.4 & 487.4 & 305.3 & 300.5 & 0.0 & 0.0 & 3567.2 \\
\hline \multirow{2}{*}{$0.1-0.3$} & Количество & 102 & 291 & 319 & 270 & 145 & 86 & 67 & 47 & 0 & 1327 \\
\hline & Запасы & 76.6 & 204.8 & 249.0 & 210.6 & 126.9 & 66.2 & 55.5 & 35.3 & 0.0 & 1024.9 \\
\hline \multirow{2}{*}{$0.03-0.1$} & Количество & 70 & 233 & 294 & 174 & 115 & 53 & 38 & 16 & 24 & 1017 \\
\hline & Запасы & 17.5 & 57.4 & 79.6 & 74.2 & 35.1 & 16.0 & 8.3 & 5.3 & 6.7 & 300.2 \\
\hline
\end{tabular}


Табл. 3. Распределение начальных извлекаемых запасов нефти на 01.01.2019 г. по месторождениям и залежам различной крупности в Западно-Сибирской НГП, млн. т

\begin{tabular}{|c|c|c|c|c|c|c|c|c|c|c|c|}
\hline \multirow{2}{*}{$\begin{array}{c}\text { Классы } \\
\text { залежей по } \\
\text { извлекаемым } \\
\text { запасам }\end{array}$} & \multirow[b]{2}{*}{ Параметры } & \multicolumn{9}{|c|}{ Классы месторождений по извлекаемым запасам } & \multirow[b]{2}{*}{ Всего } \\
\hline & & $\begin{array}{c}\text { более } \\
300\end{array}$ & $100-300$ & $30-100$ & $10-30$ & $3-10$ & $1-3$ & $0.3-1$ & $0.1-0.3$ & $0.03-0.1$ & \\
\hline \multicolumn{2}{|c|}{ Количество месторождений } & 15 & 50 & 109 & 137 & 179 & 156 & 118 & 32 & 10 & 806 \\
\hline \multicolumn{2}{|c|}{ Количество залежей } & 700 & 1551 & 1627 & 1192 & 795 & 409 & 233 & 63 & 24 & 6594 \\
\hline \multicolumn{2}{|c|}{ Суммарные запасы } & 12717.7 & 8679.8 & 5934.9 & 2460.0 & 1168.5 & 330.9 & 86.3 & 9.3 & 1.4 & 31388.8 \\
\hline \multirow{2}{*}{ более 300} & Количество & 8 & 0 & 0 & 0 & 0 & 0 & 0 & 0 & 0 & 8 \\
\hline & Запасы & 4042.0 & 0.0 & 0.0 & 0.0 & 0.0 & 0.0 & 0.0 & 0.0 & 0.0 & 4042.0 \\
\hline \multirow{2}{*}{$100-300$} & Количество & 31 & 8 & 0 & 0 & 0 & 0 & 0 & 0 & 0 & 39 \\
\hline & Запасы & 5057.1 & 1260.3 & 0.0 & 0.0 & 0.0 & 0.0 & 0.0 & 0.0 & 0.0 & 6317.3 \\
\hline \multirow{2}{*}{$30-100$} & Количество & 31 & 73 & 37 & 0 & 0 & 0 & 0 & 0 & 0 & 141 \\
\hline & Запасы & 1614.3 & 3982.9 & 1632.9 & 0.0 & 0.0 & 0.0 & 0.0 & 0.0 & 0.0 & 7230.1 \\
\hline \multirow{2}{*}{$10-30$} & Количество & 62 & 87 & 126 & 53 & 0 & 0 & 0 & 0 & 0 & 328 \\
\hline & Запасы & 1032.9 & 1505.5 & 2232.0 & 776.2 & 0.0 & 0.0 & 0.0 & 0.0 & 0.0 & 5546.5 \\
\hline \multirow{2}{*}{$3-10$} & Количество & 111 & 208 & 239 & 195 & 142 & 0 & 0 & 0 & 0 & 895 \\
\hline & Запасы & 612.8 & 1148.9 & 1343.2 & 1038.2 & 697.8 & 0.0 & 0.0 & 0.0 & 0.0 & 4840.8 \\
\hline \multirow{2}{*}{$1-3$} & Количество & 133 & 304 & 249 & 222 & 185 & 136 & 0 & 0 & 0 & 1229 \\
\hline & Запасы & 245.4 & 522.5 & 444.1 & 424.4 & 321.5 & 234.7 & 0.0 & 0.0 & 0.0 & 2192.6 \\
\hline \multirow{2}{*}{$0.3-1$} & Количество & 152 & 347 & 363 & 278 & 208 & 134 & 128 & 0 & 0 & 1610 \\
\hline & Запасы & 89.6 & 193.1 & 205.2 & 159.2 & 115.0 & 77.7 & 71.6 & 0.0 & 0.0 & 911.3 \\
\hline \multirow{2}{*}{$0.1-0.3$} & Количество & 102 & 291 & 319 & 270 & 145 & 86 & 67 & 47 & 0 & 1327 \\
\hline & Запасы & 19.3 & 53.1 & 59.8 & 51.0 & 27.0 & 15.3 & 12.7 & 8.3 & 0.0 & 246.4 \\
\hline \multirow{2}{*}{$0.03-0.1$} & Количество & 70 & 233 & 294 & 174 & 115 & 53 & 38 & 16 & 24 & 1017 \\
\hline & Запасы & 4.4 & 13.6 & 17.9 & 10.9 & 7.1 & 3.2 & 2.1 & 1.0 & 1.4 & 61.7 \\
\hline
\end{tabular}


Табл. 4. Последовательность выявления количества месторождений по классам крупности в Западно-Сибирской НГП в $1960-2018$ гг., Шт.

\begin{tabular}{|c|c|c|c|c|c|c|c|c|c|c|}
\hline \multirow{2}{*}{ Годы } & \multicolumn{10}{|c|}{ Классы крупности по извлекаемым запасам, млн. т } \\
\cline { 2 - 13 } & $>300$ & $100-300$ & $30-100$ & $10-30$ & $3-10$ & $1-3$ & $0.3-1$ & $0.1-0.3$ & $0.03-0.1$ & Всего \\
\hline $1960-1970$ & 9 & 17 & 18 & 14 & 9 & 12 & 3 & 0 & 0 & 82 \\
\hline $1971-1980$ & 2 & 18 & 28 & 22 & 17 & 7 & 3 & 2 & 0 & 99 \\
\hline $1981-1990$ & 3 & 11 & 41 & 53 & 69 & 47 & 27 & 6 & 0 & 257 \\
\hline $1991-2000$ & 1 & 2 & 11 & 23 & 31 & 40 & 28 & 3 & 2 & 141 \\
\hline $2001-2010$ & 0 & 2 & 8 & 15 & 33 & 31 & 38 & 15 & 7 & 149 \\
\hline $2011-2015$ & 0 & 0 & 2 & 7 & 15 & 14 & 13 & 4 & 1 & 56 \\
\hline 2016 & 0 & 0 & 0 & 1 & 2 & 3 & 2 & 0 & 0 & 8 \\
\hline 2017 & 0 & 0 & 1 & 1 & 3 & 2 & 3 & 2 & 0 & 12 \\
\hline 2018 & 0 & 0 & 0 & 1 & 0 & 0 & 1 & 0 & 0 & 2 \\
\hline Всего & 15 & 50 & 109 & 137 & 179 & 156 & 118 & 32 & 10 & 806 \\
\hline
\end{tabular}


Табл. 5. Суммарные извлекаемые запасы месторождений по классам крупности выявленные в Западно-Сибирской НГП в $1960-2018$ гг., млн. т

\begin{tabular}{|c|c|c|c|c|c|c|c|c|c|c|}
\hline \multirow{2}{*}{ Годы } & \multicolumn{10}{|c|}{ Классы крупности по извлекаемым запасам, млн. т } \\
\cline { 2 - 13 } & $>300$ & $100-300$ & $30-100$ & $10-30$ & $3-10$ & $1-3$ & $0.3-1$ & $0.1-0.3$ & $0.03-0.1$ & Всего \\
\hline $1960-1970$ & 8275.7 & 3525.0 & 1122.5 & 246.8 & 60.7 & 24.4 & 2.3 & 0.0 & 0.0 & 13257.5 \\
\hline $1971-1980$ & 1202.6 & 3127.3 & 1510.5 & 406.1 & 99.7 & 14.0 & 1.6 & 0.4 & 0.0 & 6362.3 \\
\hline $1981-1990$ & 2769.2 & 1568.0 & 2117.5 & 964.1 & 432.9 & 81.8 & 16.4 & 1.3 & 0.0 & 7951.4 \\
\hline $1991-2000$ & 470.1 & 217.8 & 620.6 & 388.1 & 182.1 & 75.6 & 19.0 & 0.5 & 0.1 & 1974.0 \\
\hline $2001-2010$ & 0.0 & 241.7 & 407.4 & 236.1 & 200.3 & 58.0 & 22.9 & 2.5 & 0.5 & 1169.4 \\
\hline $2011-2015$ & 0.0 & 0.0 & 126.3 & 107.1 & 78.6 & 29.2 & 8.2 & 0.7 & 0.04 & 350.2 \\
\hline 2016 & 0.0 & 0.0 & 0.0 & 21.2 & 12.4 & 5.2 & 0.9 & 0.0 & 0.00 & 39.8 \\
\hline 2017 & 0.0 & 0.0 & 30.0 & 12.4 & 18.8 & 3.8 & 2.4 & 0.4 & 0.00 & 67.8 \\
\hline 2018 & 0.0 & 0.0 & 0.0 & 21.4 & 0.0 & 0.0 & 0.4 & 0.0 & 0.00 & 21.8 \\
\hline Всего & 12717.7 & 8679.8 & 5934.9 & 2403.4 & 1085.6 & 292.1 & 74.0 & 5.9 & 0.6 & 31194.0 \\
\hline
\end{tabular}


Табл. 6. Оценка начальных геологических и извлекаемых ресурсов нефти при минимальных ресурсах оцениваемых залежей 0.03 млн. т, Западно-Сибирской НГП по состоянию на 01.01.2019 г., млн. т

\begin{tabular}{|c|c|c|c|c|c|c|c|c|c|c|}
\hline \multirow{2}{*}{ Параметр } & \multicolumn{9}{|c|}{ Класс залежей по извлекаемым запасам } & Всего \\
\cline { 2 - 12 } & более 300 & $100-300$ & $30-100$ & $10-30$ & $3-10$ & $1-3$ & $0.3-1$ & $0.1-0.3$ & $0.03-0.1$ & \\
\hline Геологические & 8679.2 & 19136.9 & 7 & 7 & 5 & $\begin{array}{c}24362 . \\
2\end{array}$ & $\begin{array}{c}27293 . \\
6\end{array}$ & $\begin{array}{c}26565 . \\
8\end{array}$ & 34068.0 & 207711.9 \\
\hline Извлекаемые & 4042.0 & 6317.3 & 7283.5 & 5645.2 & 7479.1 & 6334.7 & 6979.3 & 6385.6 & 6976.0 & 57442.6 \\
\hline $\begin{array}{c}\text { Количество } \\
\text { залежей }\end{array}$ & 8 & 39 & 142 & 334 & 1394 & 3819 & 13513 & 38728 & 135084 & 193061 \\
\hline
\end{tabular}



Табл. 7. Коэффициент извлечения нефти по классам крупности

\begin{tabular}{|c|c|c|c|c|c|c|c|c|c|}
\hline $\begin{array}{c}\text { Классы залежей } \\
\text { по извлекаемым } \\
\text { запасам, млн. т }\end{array}$ & $\begin{array}{c}\text { Более } \\
300\end{array}$ & $100-300$ & $100-30$ & $30-10$ & $10-3$ & $3-1$ & $1-0.3$ & $0.3-0.1$ & $0.1-0.03$ \\
\hline $\begin{array}{c}\text { Коэффициент } \\
\text { извлечения }\end{array}$ & 0.47 & 0.33 & 0.32 & 0.30 & 0.29 & 0.27 & 0.26 & 0.24 & 0.20 \\
\hline
\end{tabular}


Табл. 8. Оценка прогнозных геологических и извлекаемых ресурсов нефти Западно-Сибирской НГП по состоянию на 01.01.2019 г., Млн. Т

\begin{tabular}{|c|c|c|c|c|c|c|c|c|}
\hline \multirow{2}{*}{ Параметр } & \multicolumn{7}{|c|}{ Класс залежей по извлекаемым запасам } & \multirow{2}{*}{ Всего } \\
\cline { 2 - 10 } & $30-100$ & $10-30$ & $3-10$ & $1-3$ & $0.3-1$ & $0.1-0.3$ & $0.03-0.1$ & \\
\hline Геологические & 157.8 & 331.5 & 9116.2 & 16250.7 & 23726.4 & 25540.9 & 33767.7 & 108891.2 \\
\hline Извлекаемые & 53.4 & 98.7 & 2638.2 & 4142.1 & 6067.9 & 6139.1 & 6914.3 & 26053.8 \\
\hline Количество залежей & 1 & 6 & 499 & 2590 & 11903 & 37401 & 134067 & 186467 \\
\hline
\end{tabular}


Табл. 9. Сравнение оценок начальных суммарных ресурсов нефти в Западно-Сибирской нефтегазоносной провинции в зависимости от минимальных ресурсов, учитываемых при оценке залежей, по состоянию на 01.01.2019 г., млн. т

\begin{tabular}{|c|c|c|c|c|}
\hline \multicolumn{2}{|c|}{ Параметр } & \multicolumn{3}{|c|}{ Оценка НСР } \\
\hline \multicolumn{2}{|c|}{$\begin{array}{c}\text { Минимальные запасы залежей, } \\
\text { учитываемых при оценке }\end{array}$} & более 0.3 & более 0.1 & более 0.03 \\
\hline \multirow{2}{*}{ Ресурсы } & геологические & 147078.1 & 173644.0 & 207711.9 \\
\cline { 2 - 5 } & извлекаемые & 44081.1 & 50466.7 & 57442.6 \\
\hline
\end{tabular}


Табл. 10. Распределение начальных геологических и извлекаемых ресурсов нефти Западно-Сибирской нефтегазоносной провинции по категориям запасов и ресурсов, млн. т

\begin{tabular}{|c|c|c|c|c|c|}
\hline Параметры & \multirow{2}{*}{ Накопленная } & \multicolumn{2}{|c|}{ Запасы } & \multicolumn{2}{|c|}{ Ресурсы } \\
\cline { 1 - 1 } \cline { 6 - 7 } Категории запасов, ресурсов & добыча & $\mathrm{A}+\mathrm{B}+\mathrm{C}_{1}$ & $\mathrm{C}_{2}$ & $\mathrm{D}_{1}$ & $\mathrm{HCP}$ \\
\hline
\end{tabular}

1. Учтены залежи с запасами более 0.03 млн. т

\begin{tabular}{|c|c|c|c|c|c|c|}
\hline \multirow{2}{*}{ Ресурсы } & геологические & $38511.6^{*}$ & 55717.6 & 31343 & 82139.7 & 207711.9 \\
\cline { 2 - 7 } & извлекаемые & 12399.6 & 11800.1 & 7350.2 & 25892.7 & 57442.6 \\
\hline
\end{tabular}

2. Учтены залежи с запасами более 0.1 млн. т

\begin{tabular}{|c|c|c|c|c|c|c|}
\hline \multirow{2}{*}{ Ресурсы } & геологические & $38511.6^{*}$ & 56353.4 & 31343 & 47436.0 & 173644.0 \\
\cline { 2 - 7 } & извлекаемые & 12399.6 & 11973.3 & 7350.2 & 18743.6 & 50466.7 \\
\hline
\end{tabular}

3. Учтены залежи с запасами более 0.3 млн. т

\begin{tabular}{|c|c|c|c|c|c|c|}
\hline \multirow{2}{*}{ Ресурсы } & геологические & $38511.6^{*}$ & 56353.4 & 31343 & 20870.1 & 147078.1 \\
\cline { 2 - 7 } & извлекаемые & 12399.6 & 11973.3 & 7350.2 & 12358.0 & 44081.1 \\
\hline
\end{tabular}

* сумма накопленной добычи и оставшихся в недрах неизвлеченных ресурсов на разрабатываемых месторождениях 
Табл. 11. Среднее количество залежей, приходящихся на одно месторождение в прогнозируемых классах крупности

\begin{tabular}{|c|c|c|c|c|c|c|c|c|c|}
\hline \multirow{2}{*}{ Параметры } & \multicolumn{9}{|c|}{ Классы месторождений по извлекаемым запасам, млн. т } \\
\hline & Более 300 & $100-300$ & $30-100$ & $10-30$ & $3-10$ & $1-3$ & $0.3-1$ & $0.1-0.3$ & $0.03-0.1$ \\
\hline Кол-во месторождений & 15 & 50 & 109 & 137 & 179 & 156 & 118 & 32 & 10 \\
\hline Кол-во залежей & 700 & 1551 & 1627 & 1192 & 795 & 409 & 233 & 63 & 24 \\
\hline Среднее количество залежей & 47 & 31 & 15 & 9 & 4 & 3 & 2 & 2 & 2 \\
\hline Минимум-максимум & 3-111 & $2-163$ & $1-89$ & $1-43$ & $1-16$ & $1-11$ & $1-5$ & $1-2$ & $1-1$ \\
\hline
\end{tabular}


Табл. 12. Распределение начальных геологических ресурсов нефти по состоянию на 01.01.2019 г. по месторождениям и залежам различной крупности в Западно-Сибирской НГП, млн. т

\begin{tabular}{|c|c|c|c|c|c|c|c|c|c|c|c|}
\hline \multirow{2}{*}{$\begin{array}{c}\text { Классы } \\
\text { залежей по } \\
\text { извлекаемым } \\
\text { запасам }\end{array}$} & \multirow[b]{2}{*}{ Параметры } & \multicolumn{9}{|c|}{ Классы месторождений по извлекаемым запасам } & \multirow[t]{2}{*}{ Всего } \\
\hline & & $\begin{array}{c}\text { более } \\
300\end{array}$ & $100-300$ & $30-100$ & $10-30$ & $3-10$ & $1-3$ & $0.3-1$ & $0.1-0.3$ & $0.03-0.1$ & \\
\hline \multicolumn{2}{|c|}{ Количество месторождений } & 15 & 50 & 110 & 144 & 1709 & 2011 & 7498 & 30044 & 97830 & 139411 \\
\hline \multicolumn{2}{|c|}{ Количество залежей } & 700 & 1551 & 1630 & 1552 & 12228 & 14193 & 21172 & 42205 & 97830 & 193061 \\
\hline \multicolumn{2}{|c|}{ Суммарные ресурсы } & $\begin{array}{c}37080 . \\
5 \\
\end{array}$ & 27070.7 & $\begin{array}{c}19737 . \\
3 \\
\end{array}$ & $\begin{array}{c}13191 . \\
1\end{array}$ & $\begin{array}{c}29988 . \\
9\end{array}$ & $\begin{array}{c}21780 . \\
8\end{array}$ & $\begin{array}{c}18455 . \\
6 \\
\end{array}$ & \begin{tabular}{|c|}
17239. \\
1 \\
\end{tabular} & 23168.0 & 207711.9 \\
\hline \multirow{2}{*}{ более 300} & Количество & 8 & 0 & 0 & 0 & 0 & 0 & 0 & 0 & 0 & 8 \\
\hline & Ресурсы & 8679.2 & 0.0 & 0.0 & 0.0 & 0.0 & 0.0 & 0.0 & 0.0 & 0.0 & 8679.2 \\
\hline \multirow{2}{*}{$100-300$} & Количество & 31 & 8 & 0 & 0 & 0 & 0 & 0 & 0 & 0 & 39 \\
\hline & Ресурсы & 15217.8 & 3919.1 & 0.0 & 0.0 & 0.0 & 0.0 & 0.0 & 0.0 & 0.0 & 19136.9 \\
\hline \multirow{2}{*}{$30-100$} & Количество & 31 & 73 & 38 & 0 & 0 & 0 & 0 & 0 & 0 & 142 \\
\hline & Ресурсы & 5694.4 & 11799.3 & 5171.0 & 0.0 & 0.0 & 0.0 & 0.0 & 0.0 & 0.0 & 22664.7 \\
\hline \multirow{2}{*}{$10-30$} & Количество & 62 & 87 & 126 & 59 & 0 & 0 & 0 & 0 & 0 & 334 \\
\hline & Ресурсы & 3779.2 & 4874.4 & 6956.1 & 3183.0 & 0.0 & 0.0 & 0.0 & 0.0 & 0.0 & 18792.7 \\
\hline \multirow{2}{*}{$3-10$} & Количество & 111 & 208 & 240 & 317 & 518 & 0 & 0 & 0 & 0 & 1394 \\
\hline & Ресурсы & 2339.4 & 3784.8 & 4793.0 & 6116.8 & 9114.5 & 0.0 & 0.0 & 0.0 & 0.0 & 26148.5 \\
\hline \multirow{2}{*}{$1-3$} & Количество & 133 & 304 & 249 & 243 & 1529 & 1361 & 0 & 0 & 0 & 3819 \\
\hline & Ресурсы & 928.5 & 1737.5 & 1673.2 & 2854.5 & 9799.0 & 7369.6 & 0.0 & 0.0 & 0.0 & 24362.4 \\
\hline \multirow{2}{*}{$0.3-1$} & Количество & 152 & 347 & 364 & 333 & 2771 & 3701 & 5845 & 0 & 0 & 13513 \\
\hline & Ресурсы & 347.9 & 693.2 & 815.3 & 702.8 & 7114.6 & 8240.7 & 9379.1 & 0.0 & 0.0 & 27293.6 \\
\hline \multirow{2}{*}{$0.1-0.3$} & Количество & 102 & 291 & 319 & 334 & 4121 & 4263 & 9827 & 19471 & 0 & 38728 \\
\hline & Ресурсы & 76.6 & 204.8 & 249.0 & 238.5 & 3156.3 & 4138.3 & 7065.1 & 11437.2 & 0.0 & 26565.8 \\
\hline \multirow{2}{*}{$0.03-0.1$} & Количество & 70 & 233 & 294 & 266 & 3289 & 4868 & 5500 & 22734 & 97830 & 135084 \\
\hline & Ресурсы & 17.5 & 57.4 & 79.6 & 95.5 & 804.5 & 2032.2 & 2011.3 & 5801.9 & 23168.0 & 34068.0 \\
\hline
\end{tabular}



Табл. 13. Распределение начальных извлекаемых ресурсов нефти на 01.01.2019 г. по месторождениям и залежам различной крупности в Западно-СибирскойНГП, млн. т

\begin{tabular}{|c|c|c|c|c|c|c|c|c|c|c|c|}
\hline \multirow{2}{*}{$\begin{array}{c}\text { Классы } \\
\text { залежей по } \\
\text { извлекаемым } \\
\text { запасам }\end{array}$} & \multirow[b]{2}{*}{ Параметры } & \multicolumn{9}{|c|}{ Классы месторождений по извлекаемым запасам } & \multirow[t]{2}{*}{ Всего } \\
\hline & & $\begin{array}{c}\text { более } \\
300\end{array}$ & $\begin{array}{l}100- \\
300\end{array}$ & $30-100$ & $10-30$ & $3-10$ & $1-3$ & $0.3-1$ & $0.1-0.3$ & $0.03-0.1$ & \\
\hline \multicolumn{2}{|c|}{ Количество месторождений } & 15 & 50 & 110 & 144 & 1709 & 2011 & 7498 & 30044 & 97830 & 139411 \\
\hline \multicolumn{2}{|c|}{ Количество залежей } & 700 & 1551 & 1630 & 1552 & 12228 & 14193 & 21172 & 42205 & 97830 & 193061 \\
\hline \multicolumn{2}{|c|}{ Суммарные ресурсы } & 12717.7 & 8679.8 & 5994.1 & 3368.0 & 8883.2 & 4973.6 & 4520.1 & 3591.8 & 4714.2 & 57442.6 \\
\hline \multirow{2}{*}{ более 300} & Количество & 8 & 0 & 0 & 0 & 0 & 0 & 0 & 0 & 0 & 8 \\
\hline & Ресурсы & 4042.0 & 0.0 & 0.0 & 0.0 & 0.0 & 0.0 & 0.0 & 0.0 & 0.0 & 4042.0 \\
\hline \multirow{2}{*}{$100-300$} & Количество & 31 & 8 & 0 & 0 & 0 & 0 & 0 & 0 & 0 & 39 \\
\hline & Ресурсы & 5057.1 & 1260.3 & 0.0 & 0.0 & 0.0 & 0.0 & 0.0 & 0.0 & 0.0 & 6317.3 \\
\hline \multirow{2}{*}{$30-100$} & Количество & 31 & 73 & 38 & 0 & 0 & 0 & 0 & 0 & 0 & 142 \\
\hline & Ресурсы & 1614.3 & 3982.9 & 1686.3 & 0.0 & 0.0 & 0.0 & 0.0 & 0.0 & 0.0 & 7283.5 \\
\hline \multirow{2}{*}{$10-30$} & Количество & 62 & 87 & 126 & 59 & 0 & 0 & 0 & 0 & 0 & 334 \\
\hline & Ресурсы & 1032.9 & 1505.5 & 2232.0 & 874.9 & 0.0 & 0.0 & 0.0 & 0.0 & 0.0 & 5645.2 \\
\hline \multirow{2}{*}{$3-10$} & Количество & 111 & 208 & 240 & 317 & 518 & 0 & 0 & 0 & 0 & 1394 \\
\hline & Ресурсы & 612.8 & 1148.9 & 1348.2 & 1765.1 & 2604.1 & 0.0 & 0.0 & 0.0 & 0.0 & 7479.1 \\
\hline \multirow{2}{*}{$1-3$} & Количество & 133 & 304 & 249 & 243 & 1529 & 1361 & 0 & 0 & 0 & 3819 \\
\hline & Ресурсы & 245.4 & 522.5 & 444.1 & 453.3 & 2975.6 & 1693.8 & 0.0 & 0.0 & 0.0 & 6334.7 \\
\hline \multirow{2}{*}{$0.3-1$} & Количество & 152 & 347 & 364 & 333 & 2771 & 3701 & 5845 & 0 & 0 & 13513 \\
\hline & Ресурсы & 89.6 & 193.1 & 205.9 & 196.0 & 2179.4 & 2007.5 & 2107.7 & 0.0 & 0.0 & 6979.3 \\
\hline \multirow{2}{*}{$0.1-0.3$} & Количество & 102 & 291 & 319 & 334 & 4121 & 4263 & 9827 & 19471 & 0 & 38728 \\
\hline & Ресурсы & 19.3 & 53.1 & 59.8 & 61.4 & 947.2 & 863.5 & 1991.1 & 2390.2 & 0.0 & 6385.6 \\
\hline \multirow{2}{*}{$0.03-0.1$} & Количество & 70 & 233 & 294 & 266 & 3289 & 4868 & 5500 & 22734 & 97830 & 135084 \\
\hline & Ресурсы & 4.4 & 13.6 & 17.9 & 17.3 & 176.9 & 408.8 & 421.3 & 1201.6 & 4714.2 & 6976.0 \\
\hline
\end{tabular}


Табл. 14. Сравнительная оценка извлекаемых запасов и ресурсов залежей нефти в Западно-Сибирской нефтегазоносной провинции в генеральной совокупности (ГС), выборке (открытые залежи - О3) и прогнозных ресурсах (невыявленные залежи - НЗ), млн. т.

\begin{tabular}{|c|c|c|c|c|c|c|c|c|c|c|}
\hline \multirow{2}{*}{ Параметры } & \multicolumn{7}{|c|}{ Классы залежей по извлекаемым запасам, млн. т } & \multirow{2}{*}{ Всего } \\
\cline { 2 - 11 } & более 300 & $100-300$ & $100-30$ & $30-10$ & $10-3$ & $3-1$ & $1-0.3$ & $0.3-0.1$ & $0.1-0.03$ & \\
\hline ГС & 4042.0 & 6317.3 & 7283.5 & 5645.2 & 7479.1 & 6334.7 & 6979.3 & 6385.6 & 6976.0 & 57442.6 \\
\hline О3 & 4042.0 & 6317.3 & 7230.1 & 5546.5 & 4840.8 & 2192.6 & 911.3 & 246.4 & 61.7 & 31388.8 \\
\hline Н3 & 0.0 & 0.0 & 53.4 & 98.7 & 2638.2 & 4142.1 & 6067.9 & 6139.1 & 6914.3 & 26053.8 \\
\hline
\end{tabular}


Табл. 15. Сравнительная оценка извлекаемых запасов и ресурсов залежей нефти в Западно-Сибирской нефтегазоносной провинции в генеральной совокупности (ГС), выборке (открытые залежи - ОЗ) и прогнозных ресурсах (невыявленные залежи - НЗ), в \% к ГС.

\begin{tabular}{|c|c|c|c|c|c|c|c|c|c|c|}
\hline \multirow{2}{*}{ Параметры } & \multicolumn{9}{|c|}{ Классы залежей по извлекаемым запасам, млн. т } & \multirow[t]{2}{*}{ Всегс } \\
\hline & более 300 & $100-300$ & $100-30$ & $30-10$ & $10-3$ & $3-1$ & $1-0.3$ & $0.3-0.1$ & $0.1-0.03$ & \\
\hline$\Gamma \mathrm{C}$ & 100.0 & 100.0 & 100.0 & 100.0 & 100.0 & 100.0 & 100.0 & 100.0 & 100.0 & 100.0 \\
\hline O3 & 100.0 & 100.0 & 99.3 & 98.3 & 64.7 & 34.6 & 13.1 & 3.9 & 0.9 & 54.6 \\
\hline H3 & 0.0 & 0.0 & 0.7 & 1.7 & 35.3 & 65.4 & 86.9 & 96.1 & 99.1 & 45.4 \\
\hline
\end{tabular}


Табл. 16. Сравнительная оценка количества залежей нефти в Западно-Сибирской НГП в генеральной совокупности (ГС), выборке (открытые залежи - О3) и прогнозных ресурсах (невыявленные залежи - Н3), шт.

\begin{tabular}{|c|c|c|c|c|c|c|c|c|c|c|}
\hline \multirow{2}{*}{ Параметры } & \multicolumn{9}{|c|}{ Классы залежей по извлекаемым запасам, млн. т } & \multirow{2}{*}{ Всего } \\
\hline & более 300 & $300-100$ & $100-30$ & $30-10$ & $10-3$ & 3-1 & $1-0.3$ & $0.3-0.1$ & $0.1-0.03$ & \\
\hline$\Gamma \mathrm{C}$ & 8 & 39 & 142 & 334 & 1394 & 3819 & 13513 & 38728 & 135084 & 193061 \\
\hline O3 & 8 & 39 & 141 & 328 & 895 & 1229 & 1610 & 1327 & 1017 & 6594 \\
\hline H3 & 0 & 0 & 1 & 6 & 499 & 2590 & 11903 & 37401 & 134067 & 186467 \\
\hline
\end{tabular}


Табл. 17. Сравнительная оценка количества залежей нефти в Западно-Сибирской НГП в генеральной совокупности (ГС), выборке (открытые залежи - ОЗ) и прогнозных ресурсах (невыявленные залежи - НЗ), в \% к ГС

\begin{tabular}{|c|c|c|c|c|c|c|c|c|c|c|}
\hline \multirow{2}{*}{ Параметры } & \multicolumn{9}{|c|}{ Классы залежей по извлекаемым запасам, млн. т } & \multirow{2}{*}{ Всего } \\
\hline & более 300 & $300-100$ & $100-30$ & $30-10$ & $10-3$ & 3-1 & $1-0.3$ & $0.3-0.1$ & $0.1-0.03$ & \\
\hline$\Gamma \mathrm{C}$ & 100.0 & 100.0 & 100.0 & 100.0 & 100.0 & 100.0 & 100.0 & 100.0 & 100.0 & 100 \\
\hline O3 & 100.0 & 100.0 & 99.3 & 98.2 & 64.2 & 32.2 & 11.9 & 3.4 & 0.8 & 3.4 \\
\hline H3 & 0.0 & 0.0 & 0.7 & 1.8 & 35.8 & 67.8 & 88.1 & 96.6 & 99.2 & 96.6 \\
\hline
\end{tabular}


Табл. 18. Распределение прогнозных (D0+D1) геологических ресурсов нефти, по состоянию на 01.01.2019 г. по месторождениям и залежам различной крупности в Западно-Сибирской НГП*, млн. т

\begin{tabular}{|c|c|c|c|c|c|c|c|c|c|}
\hline \multirow{2}{*}{$\begin{array}{c}\text { Классы } \\
\text { залежей по } \\
\text { извлекаемы } \\
\text { м запасам } \\
\end{array}$} & \multirow[b]{2}{*}{ Параметры } & \multicolumn{7}{|c|}{ Классы месторождений по извлекаемым запасам } & \multirow[b]{2}{*}{ Всего } \\
\hline & & $30-100$ & $10-30$ & $3-10$ & $1-3$ & $0.3-1$ & $0.1-0.3$ & $0.03-0.1$ & \\
\hline \multicolumn{2}{|c|}{ Количество месторождений } & 1 & 7 & 1530 & 1855 & 7380 & 30012 & 97820 & 138605 \\
\hline \multicolumn{2}{|c|}{ Количество залежей } & 3 & 360 & 11433 & 13784 & 20939 & 42142 & 97806 & 186467 \\
\hline \multicolumn{2}{|c|}{ Суммарные ресурсы } & 166.872 & 4198.28 & 25565.5 & $\begin{array}{c}20509 . \\
6\end{array}$ & $\begin{array}{c}18091 . \\
3\end{array}$ & $\begin{array}{c}17198 . \\
4\end{array}$ & 23161.3 & $\begin{array}{c}108891 . \\
2\end{array}$ \\
\hline \multirow{2}{*}{$30-100$} & Количество & 1 & 0 & 0 & 0 & 0 & 0 & 0 & 1 \\
\hline & Ресурсы & 157.8 & 0.0 & 0.0 & 0.0 & 0.0 & 0.0 & 0.0 & 157.8 \\
\hline \multirow{2}{*}{$10-30$} & Количество & 0 & 6 & 0 & 0 & 0 & 0 & 0 & 6 \\
\hline & Ресурсы & 0.0 & 331.54 & 0.0 & 0.0 & 0.0 & 0.0 & 0.0 & 331.5 \\
\hline \multirow{2}{*}{$3-10$} & Количество & 1 & 122 & 376 & 0 & 0 & 0 & 0 & 499 \\
\hline & Ресурсы & 7.3 & 2513.5 & 6595.5 & 0.0 & 0.0 & 0.0 & 0.0 & 9116.2 \\
\hline \multirow{2}{*}{$1-3$} & Количество & 0 & 21 & 1344 & 1225 & 0 & 0 & 0 & 2590 \\
\hline & Ресурсы & 0.0 & 1220.7 & 8544.1 & 6485.8 & 0.0 & 0.0 & 0.0 & 16250.7 \\
\hline \multirow{2}{*}{$0.3-1$} & Количество & 1 & 55 & 2563 & 3567 & 5717 & 0 & 0 & 11903 \\
\hline & Ресурсы & 1.8 & 83.4 & 6627.1 & 7935.4 & 9078.6 & 0.0 & 0.0 & 23726.4 \\
\hline \multirow[b]{2}{*}{$0.1-0.3$} & Количество & 0 & 64 & 3976 & 4177 & 9760 & 19424 & 0 & 37401 \\
\hline & Ресурсы & 0.0 & 27.9 & 3029.5 & 4072.1 & 7009.6 & $\begin{array}{c}11401 . \\
8\end{array}$ & 0.0 & 25540.9 \\
\hline \multirow{2}{*}{$0.03-0.1$} & Количество & 0 & 92 & 3174 & 4815 & 5462 & 22718 & 97806 & 134067 \\
\hline & Ресурсы & 0.0 & 21.3 & 769.4 & 2016.2 & 2003.0 & 5796.6 & 23161.3 & 33767.7 \\
\hline
\end{tabular}

* анализ распределения запасов открытых залежей и динамики их выявления, позволяет заключить, что, в настоящее время, вероятность открытия скопления с запасами, превышающими 100 млн. т, близка к нулю 
Табл. 19. Распределение прогнозных (D0+D1) извлекаемых ресурсов нефти, по состоянию на 01.01.2019 г. по месторождениям и залежам различной крупности в Западно-Сибирской НГП*, млн. т

\begin{tabular}{|c|c|c|c|c|c|c|c|c|c|}
\hline \multirow{2}{*}{$\begin{array}{c}\text { Классы } \\
\text { залежей по } \\
\text { извлекаемы } \\
\text { м запасам }\end{array}$} & \multirow[b]{2}{*}{ Параметры } & \multicolumn{7}{|c|}{ Классы месторождений по извлекаемым запасам } & \multirow[t]{2}{*}{ Всего } \\
\hline & & $30-100$ & $10-30$ & $3-10$ & $1-3$ & $0.3-1$ & $0.1-0.3$ & $0.03-0.1$ & \\
\hline \multicolumn{2}{|c|}{$\begin{array}{c}\text { Количество } \\
\text { месторождений }\end{array}$} & 1 & 7 & 1530 & 1855 & 7380 & 30012 & 97820 & 138605 \\
\hline \multicolumn{2}{|c|}{ Количество залежей } & 3 & 360 & 11433 & 13784 & 20939 & 42142 & 97806 & 186467 \\
\hline \multicolumn{2}{|c|}{ Суммарные ресурсы } & 59.192 & 908.059 & 7714.8 & $\begin{array}{c}4642.7 \\
3 \\
\end{array}$ & $\begin{array}{c}4433 . \\
8 \\
\end{array}$ & $\begin{array}{c}3582.4 \\
7 \\
\end{array}$ & 4712.76 & $\begin{array}{c}26053.7 \\
9 \\
\end{array}$ \\
\hline \multirow{2}{*}{$30-100$} & Количество & 1 & 0 & 0 & 0 & 0 & 0 & 0 & 1 \\
\hline & Ресурсы & 53.4 & 0 & 0 & 0 & 0 & 0 & 0 & 53.4 \\
\hline \multirow{2}{*}{$10-30$} & Количество & 0 & 6 & 0 & 0 & 0 & 0 & 0 & 6 \\
\hline & Ресурсы & 0 & 98.7 & 0 & 0 & 0 & 0 & 0 & 98.7 \\
\hline \multirow{2}{*}{$3-10$} & Количество & 1 & 122 & 376 & 0 & 0 & 0 & 0 & 499 \\
\hline & Ресурсы & 5 & 726.9 & 1906.4 & 0 & 0 & 0 & 0 & 2638.2 \\
\hline \multirow{2}{*}{$1-3$} & Количество & 0 & 21 & 1344 & 1225 & 0 & 0 & 0 & 2590 \\
\hline & Ресурсы & 0 & 28.9 & 2654.1 & 1459.1 & 0 & 0 & 0 & 4142.1 \\
\hline \multirow[b]{2}{*}{$0.3-1$} & Количество & 1 & 55 & 2563 & 3567 & 5717 & 0 & 0 & 11903 \\
\hline & Ресурсы & 0.8 & 36.8 & 2064.4 & 1929.8 & $\begin{array}{c}2036 . \\
1\end{array}$ & 0 & 0 & 6067.9 \\
\hline \multirow[b]{2}{*}{$0.1-0.3$} & Количество & 0 & 64 & 3976 & 4177 & 9760 & 19424 & 0 & 37401 \\
\hline & Ресурсы & 0 & 10.4 & 920.2 & 848.2 & $\begin{array}{c}1978 . \\
4\end{array}$ & 2381.9 & 0 & 6139.1 \\
\hline \multirow{2}{*}{$0.03-0.1$} & Количество & 0 & 92 & 3174 & 4815 & 5462 & 22718 & 97806 & 134067 \\
\hline & Ресурсы & 0 & 6.4 & 169.8 & 405.6 & 419.2 & 1200.6 & 4712.8 & 6914.3 \\
\hline
\end{tabular}

* анализ распределения запасов открытых залежей и динамики их выявления, позволяет заключить, что, в настоящее время, вероятность открытия скопления с запасами, превышающими 100 млн. т, близка к нулю 


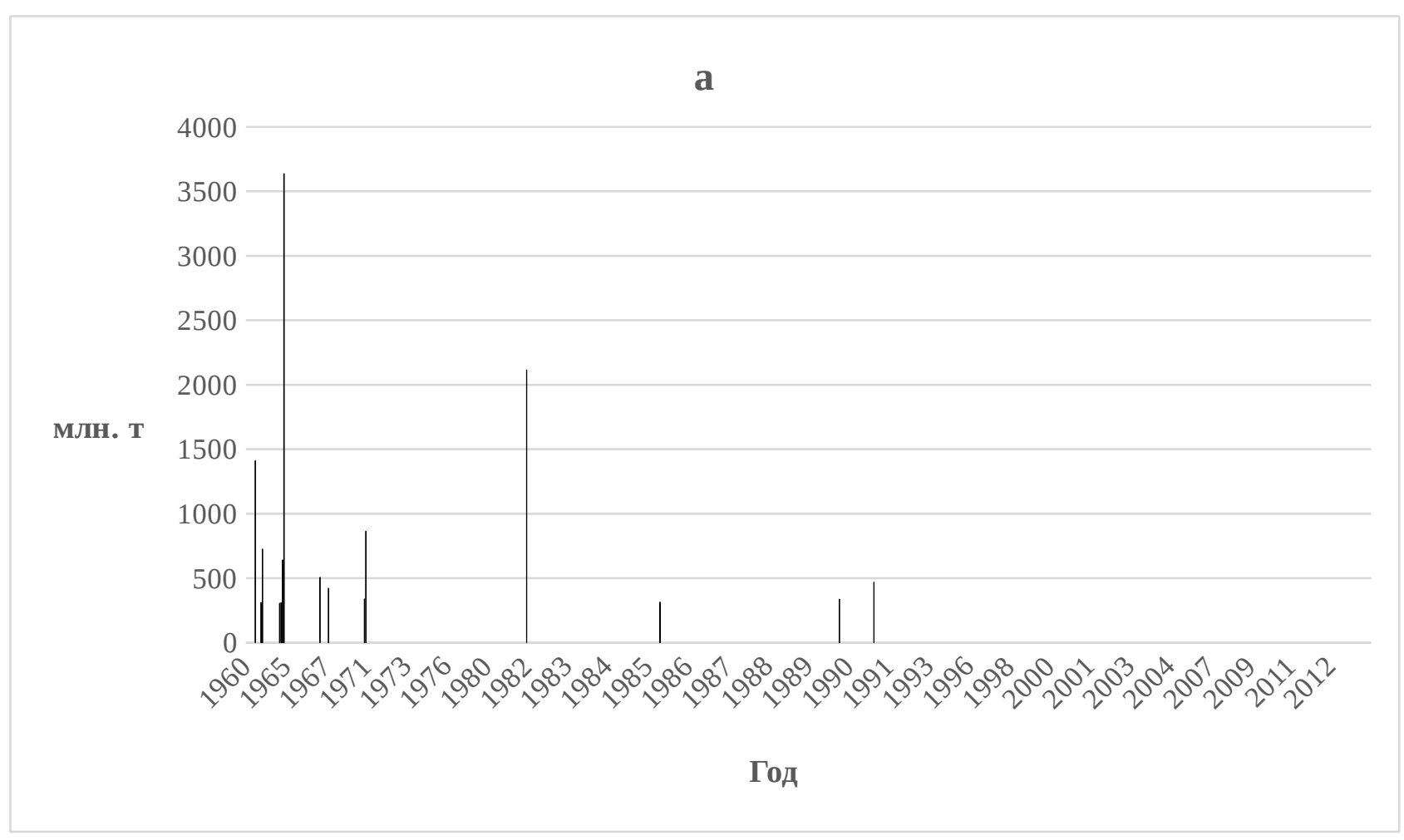




$$
350
$$

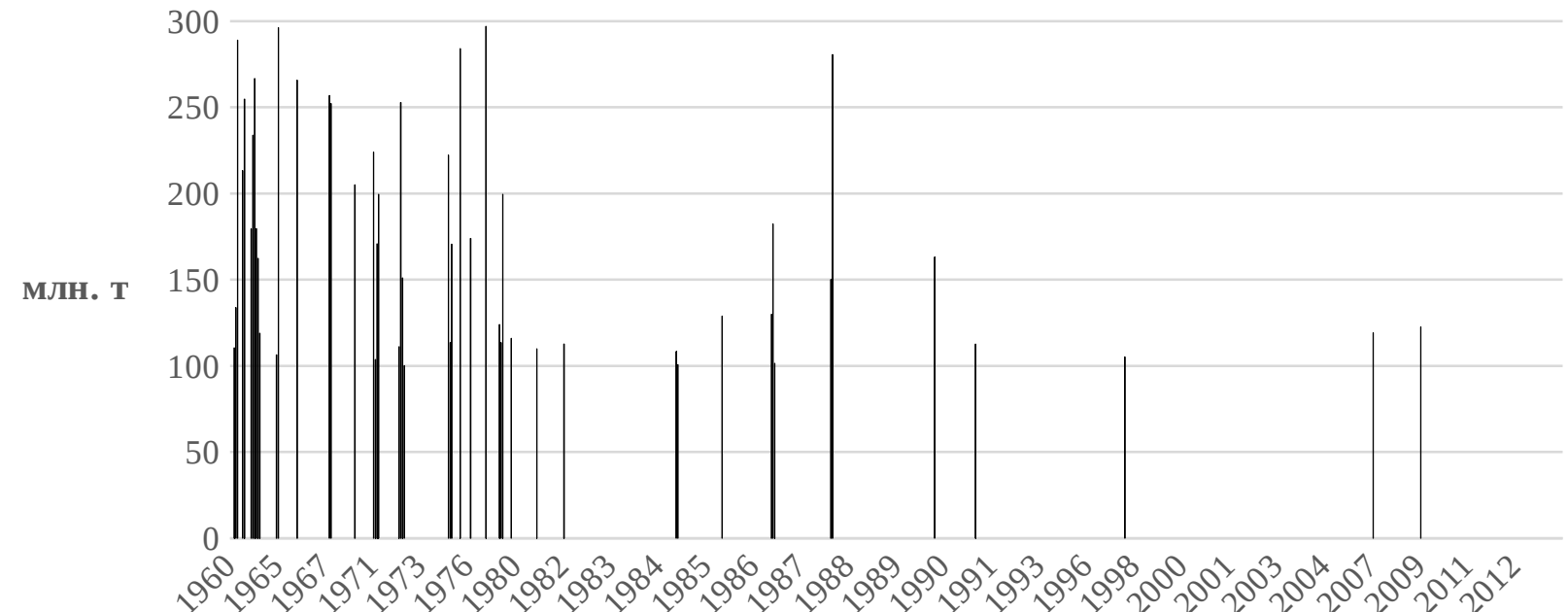

Год 


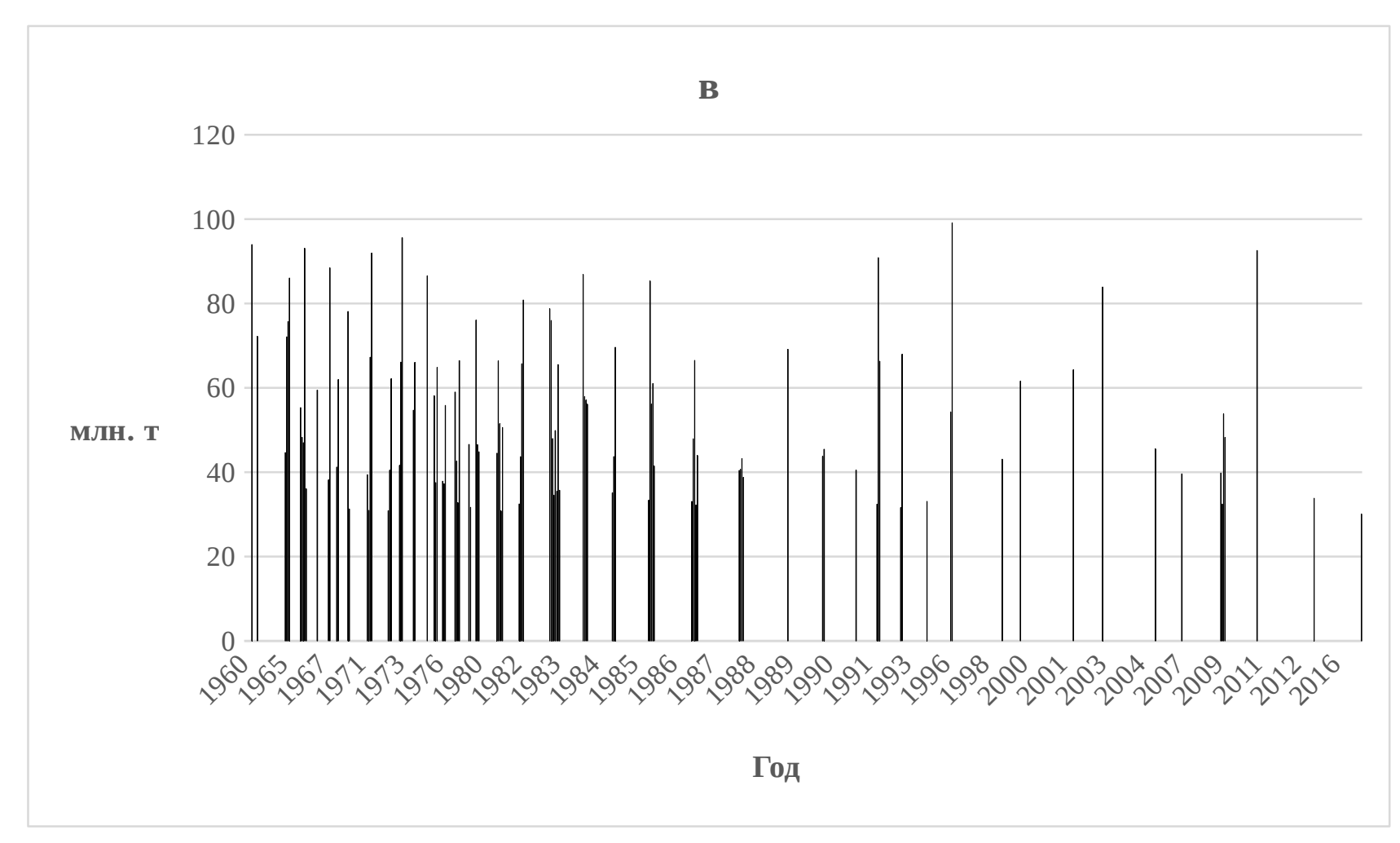




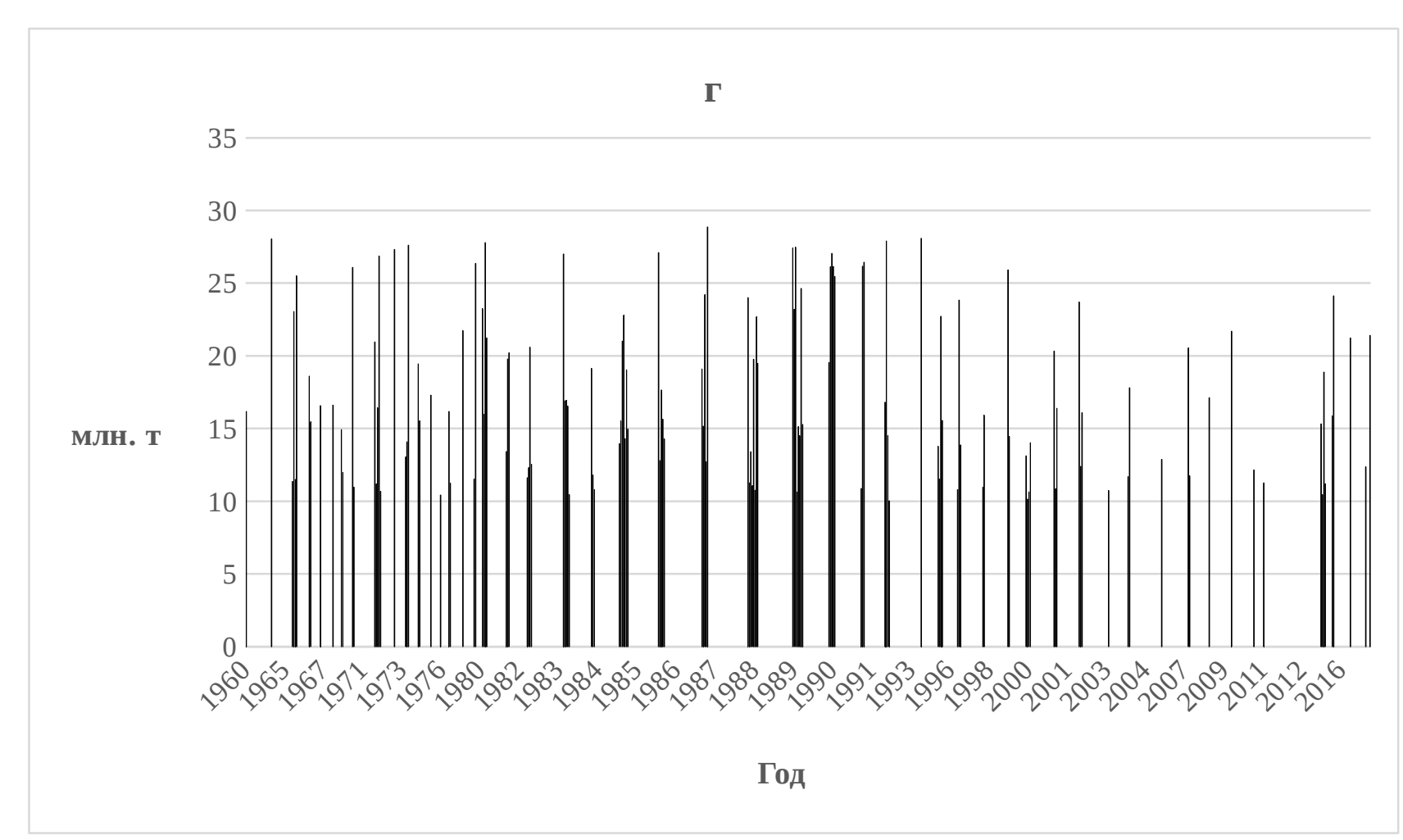




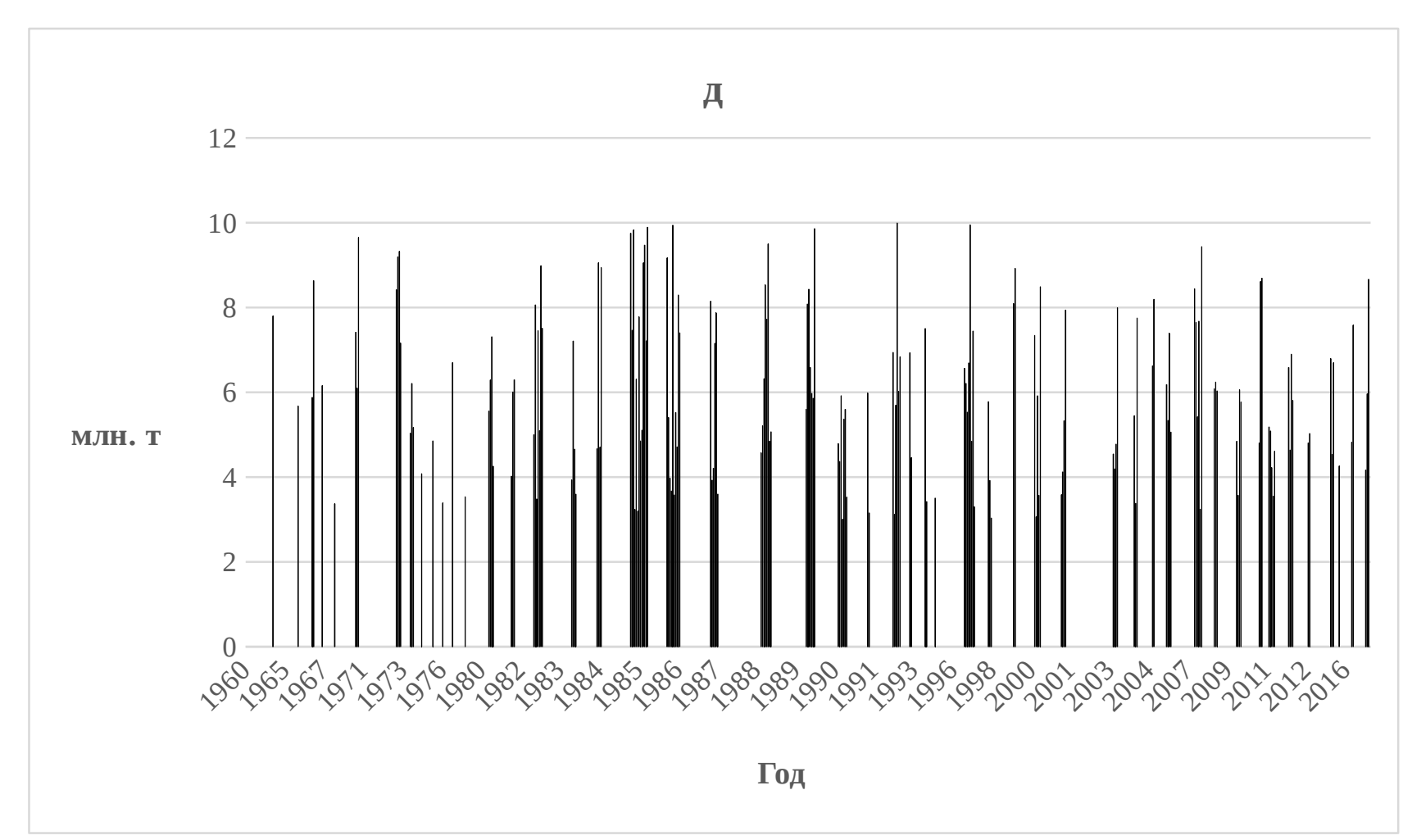




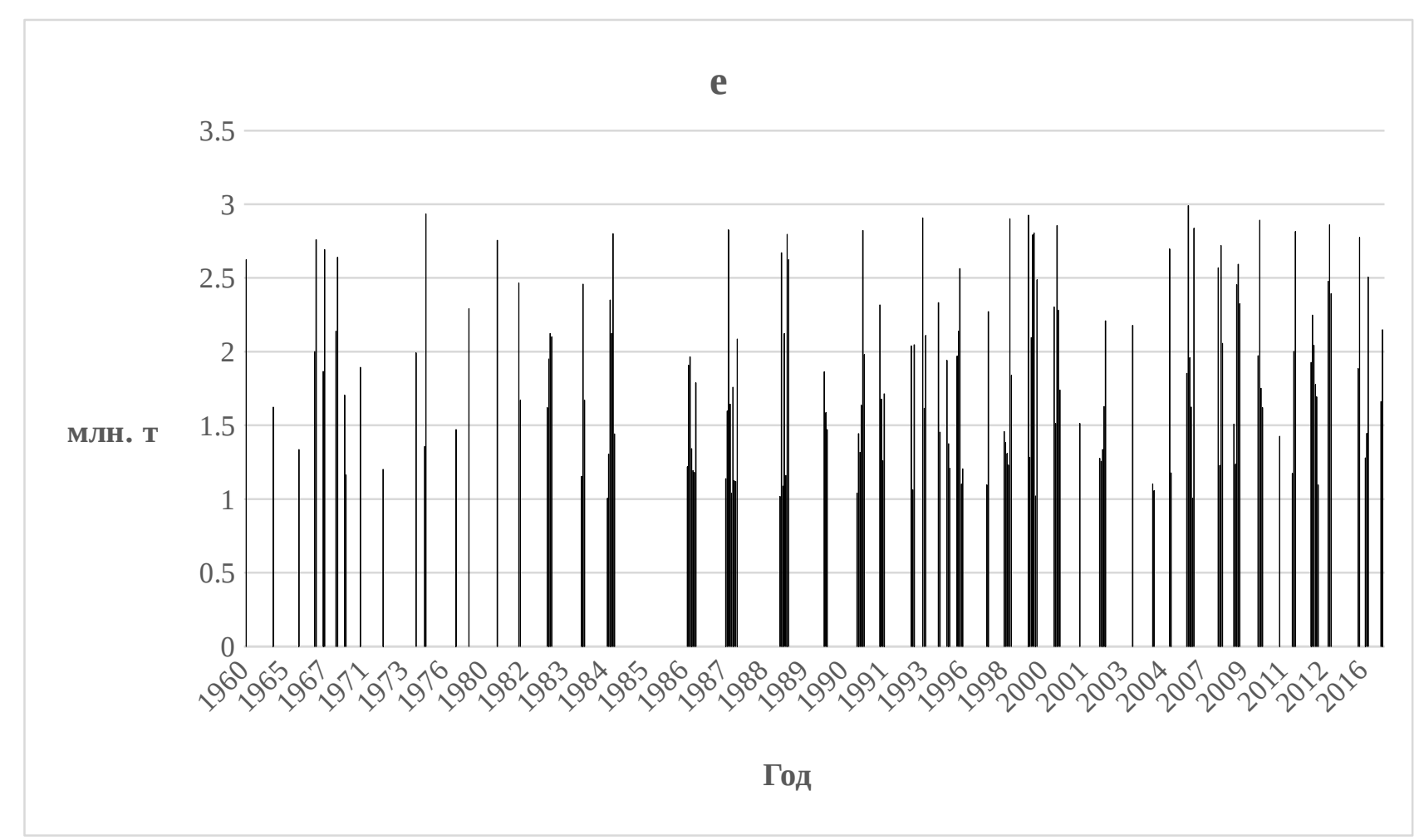




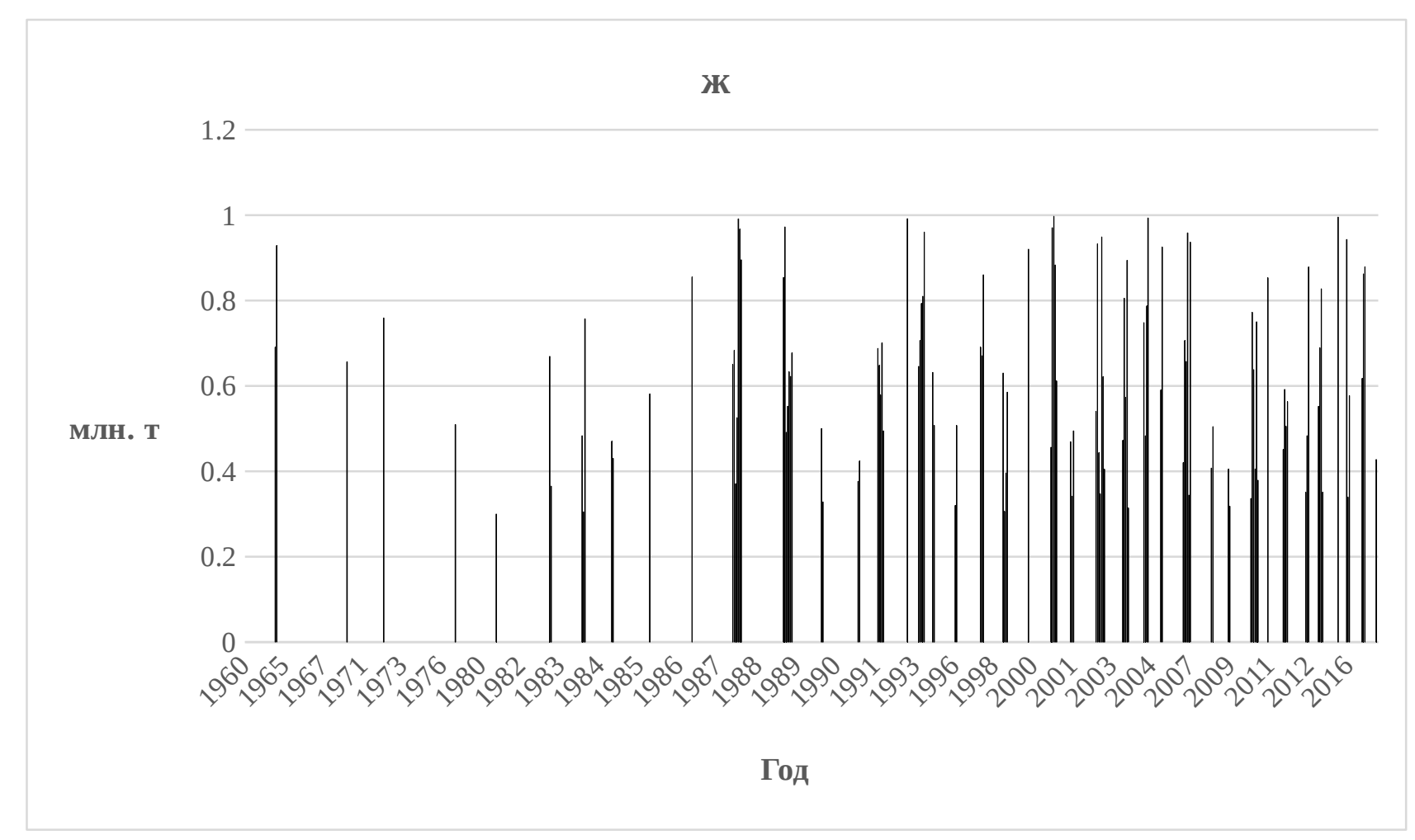


3

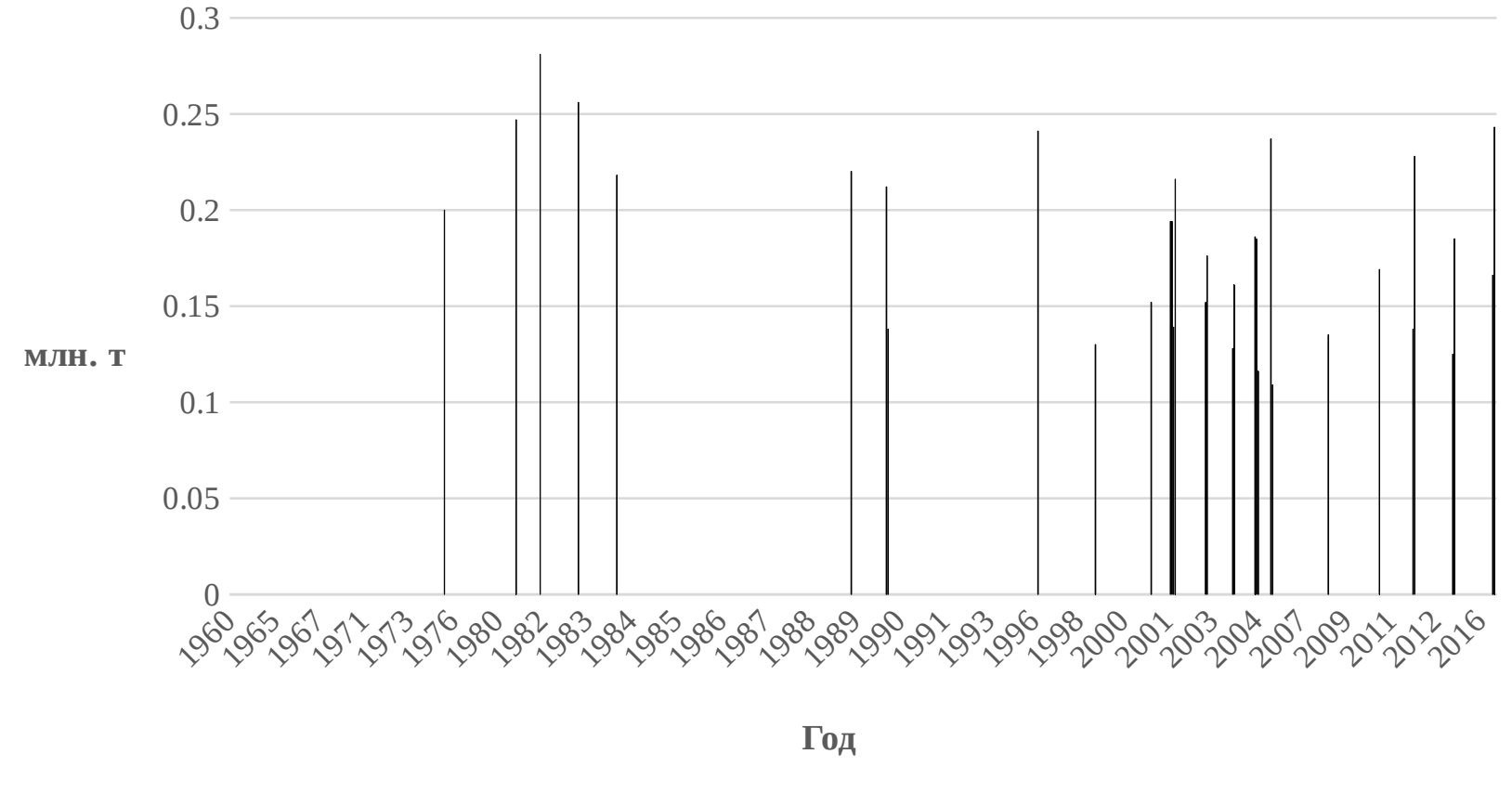




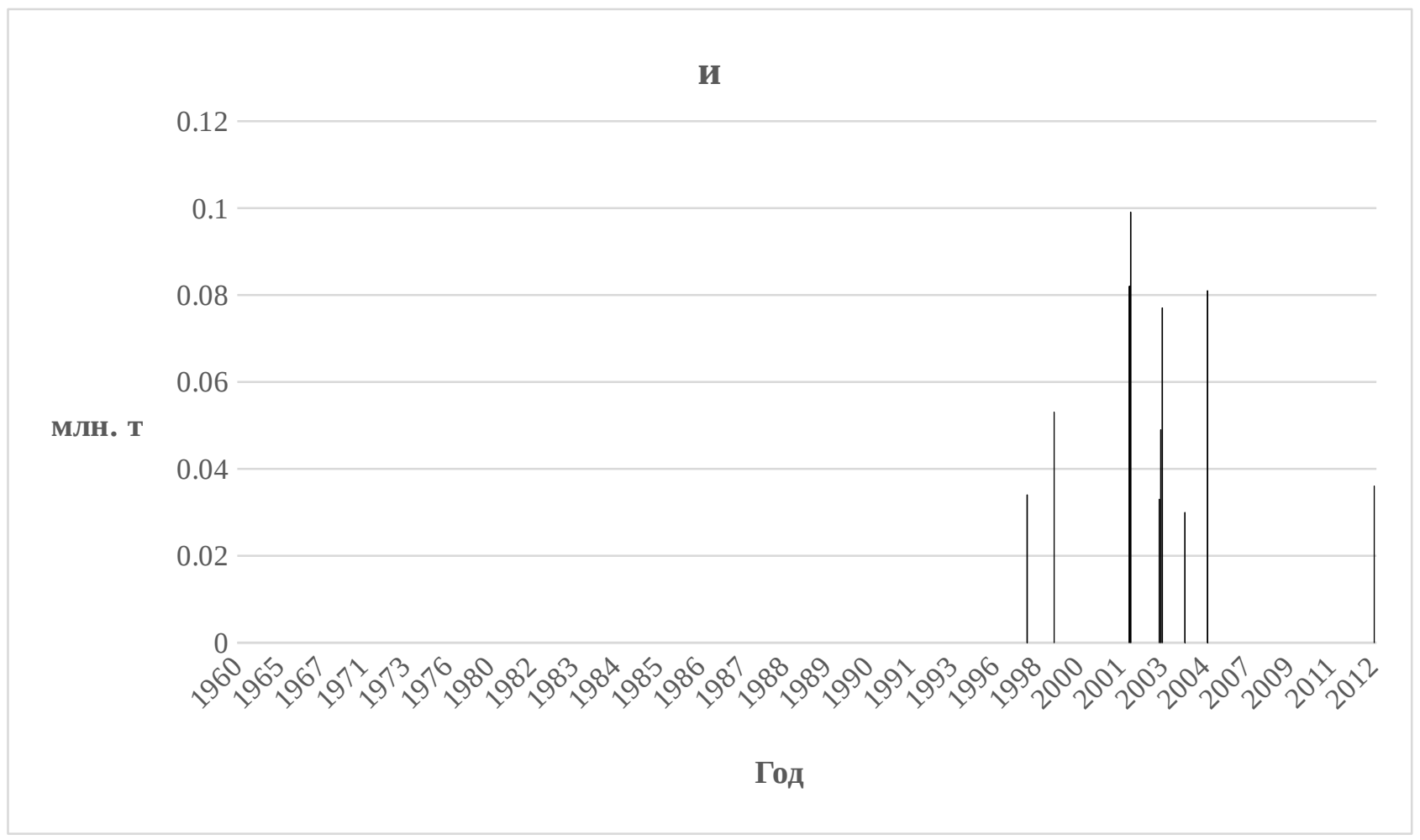

